\title{
Botanicals in Postmenopausal Osteoporosis
}

\author{
Wojciech Słupski, Paulina Jawień and Beata Nowak *(D) \\ Department of Pharmacology, Wroclaw Medical University, ul. J. Mikulicza-Radeckiego 2, \\ 50-345 Wrocław, Poland; wojciech.slupski@umed.wroc.pl (W.S.); paulina.jawien@umed.wroc.pl (P.J.) \\ * Correspondence: beata.nowak@umed.wroc.pl; Tel.: +48-607-924-471
}

check for updates

Citation: Słupski, W.; Jawień, P.; Nowak, B. Botanicals in Postmenopausal Osteoporosis. Nutrients 2021, 13, 1609. https:// doi.org/10.3390/nu13051609

Academic Editor: Jose M. Moran

Received: 9 April 2021

Accepted: 10 May 2021

Published: 11 May 2021

Publisher's Note: MDPI stays neutral with regard to jurisdictional claims in published maps and institutional affiliations.

Copyright: (c) 2021 by the authors. Licensee MDPI, Basel, Switzerland. This article is an open access article distributed under the terms and conditions of the Creative Commons Attribution (CC BY) license (https:/ / creativecommons.org/licenses/by/ $4.0 /)$.

\begin{abstract}
Osteoporosis is a systemic bone disease characterized by reduced bone mass and the deterioration of bone microarchitecture leading to bone fragility and an increased risk of fractures. Conventional anti-osteoporotic pharmaceutics are effective in the treatment and prophylaxis of osteoporosis, however they are associated with various side effects that push many women into seeking botanicals as an alternative therapy. Traditional folk medicine is a rich source of bioactive compounds waiting for discovery and investigation that might be used in those patients, and therefore botanicals have recently received increasing attention. The aim of this review of literature is to present the comprehensive information about plant-derived compounds that might be used to maintain bone health in perimenopausal and postmenopausal females.
\end{abstract}

Keywords: osteoporosis; menopause; botanicals; herbs

\section{Introduction}

Women's health and quality of life is modulated and affected strongly by hormone status. An oestrogen level that changes dramatically throughout life determines the development of women's age-associated diseases. Age-associated hormonal imbalance and oestrogen deficiency are involved in the pathogenesis of various diseases, e.g., obesity, autoimmune disease and osteoporosis. Many female patients look for natural biological products deeply rooted in folk medicine as an alternative to conventional pharmaceutics used as the prophylaxis of perimenopausal health disturbances. This review will focus on botanicals and plant derived substances that may be used to maintain bone health in perimenopausal and postmenopausal females.

Osteoporosis is a systemic bone disease characterized by the reduced bone mass and deterioration of bone microarchitecture leading to bone fragility and the increased risk of fractures [1]. Osteoporosis-associated fragility fractures constitute a major health problem all over the world. It is estimated that more than 40 million American citizens over 50 years of age are at risk of osteoporotic fractures, and that due to the demographic changes, this number will at least double until the year 2040 [2]. It is also predicted that $25 \%$ of people over 50 who have experienced osteoporotic hip fracture will die within a year [2]. Hypogonadism, mainly associated with menopause, is the main cause of osteoporosis. High social and individual costs of osteoporosis and its complications remain a challenge for health systems, especially because most of the patients with osteoporosis remain untreated. The data indicate that almost $60 \%$ patients at high risk of osteoporotic fractures are not receiving osteoprotective treatment [3]. Additionally, a decrease in the usage of antiosteoporotic drugs, especially bisphosphonates, has been observed in recent years [3]. Oral bisphosphonates, that bind to hydroxyapatite and inhibit osteoclastic bone resorption, are the drug of choice for the treatment of primary osteoporosis. However, they are associated with side effects including oesophagitis and oesophageal ulcers, jaw osteonecrosis, and atypical femoral fractions. In case of intolerance or lack of efficacy, they might be switched to intravenous bisphosphonates, strontium ranelate, denosumab, teriparatide, abaloparatide or romosozumab. As additional options in postmenopausal 
women, raloxifene and hormonal replacement therapy may be used [4]. However, as those pharmaceutics are associated with various side effects, many women seek for botanicals as an alternative therapy.

Bones undergo continuous remodelling, osteoblasts synthetize the bone matrix and, at the same time, osteoclasts degrade bone tissue. In physiological conditions, we observe the balance between the resorption and formation of bone tissue. This balance depends on the activity, differentiation, and apoptosis of bone forming osteoblasts and bone-resorbing osteoclasts. Multiple factors and signalling pathways modulate bone homeostasis (Figure 1). Bone cells' activity is controlled, among others, by growth factors (IGF-insulin-like growth factor, TGF $\beta$-tumour growth factor $\beta$, PDGF-platelet-derived growth factor), bone morphogenic proteins (BMPs), hormones (parathormone, thyroid hormones, sex hormones, insulin, prolactin, growth hormone) and vitamins (vitamin D). Wnt, BMPs and TGF $\beta$ pathways interact with other signalling molecules such as basic fibroblast growth factor (bFGF), Hedgehog (Hh) and IGF-1, and regulate the differentiation and activity of osteoclasts [5]. Runx2 (Runt-related transcription factor 2) and OSX (Osterix) are the main transcription factors involved in the modulation of osteoblast differentiation. Osteoclastogenesis is regulated by two main pathways: RANK/RANKL (Receptor Activator for Nuclear Factor $\kappa \mathrm{B} /$ Receptor Activator for Nuclear Factor $\mathrm{kB}$ Ligand) and M-CSF/c-FMS (the macrophage colony-stimulating factor/colony-stimulating factor-1 receptor) system. Parathyroid hormone (PTH) and calcitriol induce RANKL synthesis in osteoblasts and afterwards promote osteoclastogenesis through RANK activation. RANK activation is counteracted by OPG (osteoprotegerin), which is a decoy receptor of free RANKL. M-CSF/c-FMS interaction leads to mitogen-activated protein kinase (MAPK) activation that induces RANKL production and activates AKT/mTOR (protein kinase B/mechanistic target of rapamycin) pathway engaged in the survival of osteoclasts [5].

Oestrogen plays an important role in maintaining bone mineral density in both rodents and humans (Figure 2). A decrease in the oestrogen level associated with menopause leads to a decrease in bone mineral density (BMD) that increases the risk of fractures [6,7]. The protective effect of oestrogen in bone is due to many mechanisms. Oestrogen, among other things, inhibits bone resorption by the suppression of the synthesis of proinflammatory cytokines in osteoblasts via the inhibition of nuclear factor-kappa B (NFkB) signalling pathway [8]. They also activate the transcription of a gene encoding Fas Ligand (FasL) in osteoblasts. Soluble FasL (sFasL) released from the osteoblast binds to the transmembrane Fas receptor (FasR) on the osteoclast's surface and induces the apoptosis of osteoclasts [9]. Additionally, oestrogen decreases the RANKL/OPG ratio and prevents bone resorption [10].

Women's health and quality of life are modulated and affected strongly by hormone status. An oestrogen level that changes dramatically determines the development of women's age-associated diseases. Age-associated hormonal imbalance and oestrogen deficiency are involved in the pathogenesis of various diseases, e.g., obesity, autoimmune diseases, and osteoporosis. As postmenopausal osteoporosis is characterised by bone resorption that exceeds bone formation, antiresorptive drugs are one of the therapeutic options and most current therapies exert mainly antiresorptive effects. Another therapeutic solution may be the use of anabolic drugs that would enhance bone formation. Bone morphogenic protein (BMP), Wnt, and insulin-like growth factor 1 (IGF1) are the key molecules involved in the regulation of osteoblast formation and activation [11-13]. Oestrogens, SERMs (selective oestrogen receptor modulators), bisphosphonates, strontium ranelate, denosumab, teriparatide, abaloparatide or romosozumab are clinically used as effective therapies against postmenopausal osteoporosis [4]; however, their usage is associated with the established risk of the side effect. Therefore, many female patients look for natural biological products deeply rooted in folk medicine as an alternative to conventional pharmaceutics used as the prophylaxis of perimenopausal health disturbances. This review will focus on botanicals and plant-derived substances that may be used to maintain bone health in perimenopausal and postmenopausal females. The aim of the review is to present the currently available results of clinical and preclinical studies, investigating the influence 
of plant-derived extracts and compounds on menopause-associated disturbances of bone metabolism. For the purpose of the article, we defined botanicals as substances obtained or derived from plants, such as a plant part or the extract, or compounds isolated from plants or their extracts. While searching for the information in PubMed and Google Scholar, we tried not to limit our research to Chinese traditional medicine, but to broaden it by including less known European plants, e.g., Humulus lupulus L. or Equisetum arvense L. We focused on the research reported after 2010, but we did not exclude earlier studies in our review. Table 1 summarizes the information about the main active ingredients discussed in the article, and Table 2 clinical studies and their main findings.
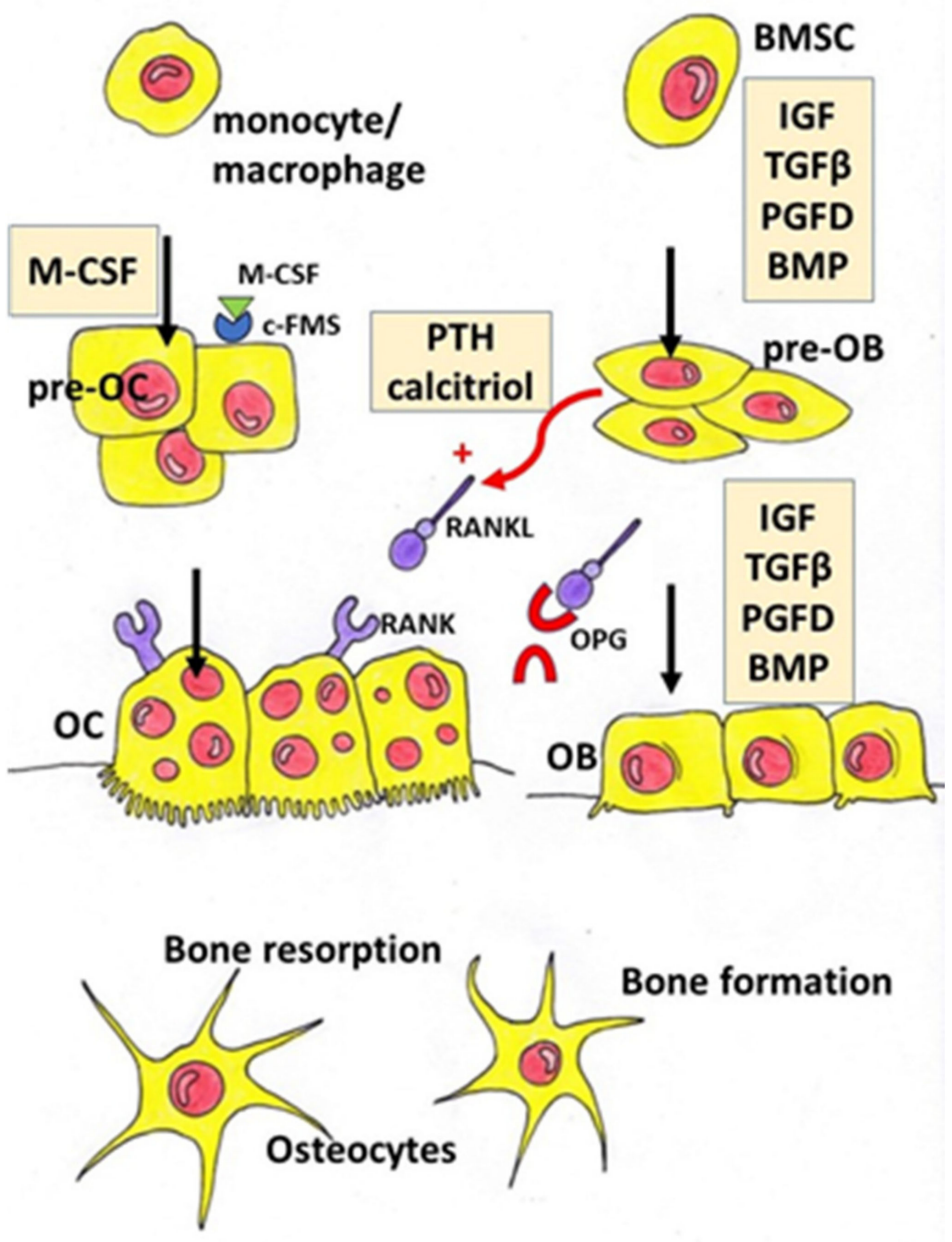

Figure 1. Schematic diagram representing regulation of osteoblast and osteoclast differentiation. $\mathrm{BMP}$ - bone morphogenic protein, BMSC — bone marrow-derived mesenchymal stem cells, c-FMScolony-stimulating factor-1 receptor, IGF-insulin-like growth factor, M-CSF-macrophage colonystimulating factor, $\mathrm{OB}$ - osteoblast, OC—osteoclast, OPG—osteoprotegerin, PGFD—platelet-derived growth factor, pre-OB-pre-osteoblasts, pre-OC-pre-osteoclasts, PTH-parathyroid hormone, RANK-Receptor Activator for Nuclear Factor kB, RANKL-Receptor Activator for Nuclear Factor кB Ligand, TGF $\beta$ - tumour growth factor $\beta$. 


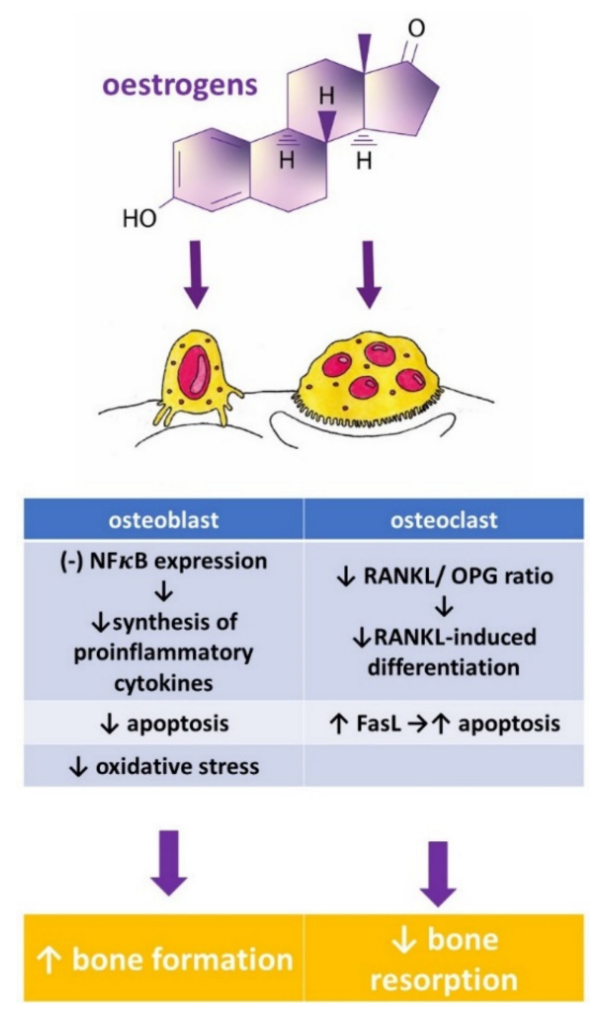

Figure 2. Influence of oestrogens on osteoblast and osteoclast function, and bone turnover. FasL-Fas Ligand, NFkB-Nuclear Factor kB, OPG—osteoprotegerin, RANKL—Receptor Activator for Nuclear Factor $\kappa \mathrm{B}$ Ligand, $\uparrow$-increased, $\downarrow$-decreased

Table 1. Herbal compounds with antiosteoporotic properties investigated in vitro and in animal models.

\begin{tabular}{|c|c|c|c|}
\hline Herbal Compounds & Subgroup & Chemical Structure & Proposed Mechanism of Action \\
\hline Daidzein & isoflavones & & $\begin{array}{c}\text { ER mediated signalling pathway, } \\
\text { activation of intracellular } \\
\text { pathways: AKT, phospholipase C } \\
\text { (PLC), mitogen-activated protein } \\
\text { kinase (MAPK) [14] }\end{array}$ \\
\hline Genistein & isoflavones & & $\begin{array}{l}\text { ER-mediated signalling pathway, } \\
\text { activation of intracellular } \\
\text { pathways: AKT, PLC, MAPK [14] }\end{array}$ \\
\hline Ipriflavone & isoflavones & & $\begin{array}{l}\text { Modulation of key signalling } \\
\text { pathways to regulate bone } \\
\text { resorption (e.g., } \downarrow \text { urinary DPD, } \\
\text { NTX) and bone formation (e.g., } \\
\uparrow \text { BALP and osteocalcin [15] }\end{array}$ \\
\hline
\end{tabular}


Table 1. Cont.

\begin{tabular}{|c|c|c|c|}
\hline Herbal Compounds & Subgroup & Chemical Structure & Proposed Mechanism of Action \\
\hline Biochanin A & $\begin{array}{l}\text { O-methylated } \\
\text { isoflavones }\end{array}$ & & $\begin{array}{l}\text { ER mediated signalling pathway, } \\
\text { activation of intracellular } \\
\text { pathways: AKT, PLC, MAPK [14] }\end{array}$ \\
\hline Formononetin & $\begin{array}{l}\text { O-methylated } \\
\text { isoflavones }\end{array}$ & & $\begin{array}{l}\text { ER mediated signalling pathway, } \\
\text { activation of intracellular } \\
\text { pathways: AKT, PLC, MAPK [14] }\end{array}$ \\
\hline Glycitein & $\begin{array}{l}\text { O-methylated } \\
\text { isoflavones }\end{array}$ & & $\begin{array}{l}\text { ER mediated signalling pathway, } \\
\text { activation of intracellular } \\
\text { pathways: AKT, PLC, MAPK [14] }\end{array}$ \\
\hline Icariin & $\begin{array}{l}\text { prenylated } \\
\text { flavonol } \\
\text { glycoside }\end{array}$ & & $\begin{array}{c}\text { Stimulation of bone formation by } \\
\text { promotion of osteoblasts } \\
\text { differentiation and enhancement } \\
\text { of their activity [16]; activation of } \\
\text { BMP-2/Smad4, Wnt and IGF-1 } \\
\text { signal transduction pathways } \\
{[5,17], \text { induction of ERK, JNK and }} \\
\text { p38 kinase activation [18]; } \\
\text { decreasing of RANKL-induced } \\
\text { osteoclastogenesis via inhibition } \\
\text { of NFKB and MAPK expression } \\
\text { [19] }\end{array}$ \\
\hline 8-prenylnaringenin & prenylflavonoids & & $\begin{array}{l}\text { Promotion of osteoblast } \\
\text { differentiation and induction of } \\
\text { osteoclast apoptosis [20] }\end{array}$ \\
\hline Epimedin B & prenylflavonoids & & $\begin{array}{l}\text { Inhibition of bone resorption, } \\
\text { bone formation promotion and } \\
\text { urinary calcium excretion } \\
\text { blocking [21] }\end{array}$ \\
\hline
\end{tabular}


Table 1. Cont.

Herbal Compounds Subgroup Proposed Mechanism of Action

Tanshinones (dihydrotanshinone, tanshinone I, or tanshinone IIA) diterpenes<smiles>Cc1coc2c1C(=O)C(=O)c1c-2ccc2c(C)cccc12</smiles>

Inhibition of the TRAP5b-expressing osteoclasts formation by suppressing RANKL-induced expression of c-fos and NFATc1 $[22,23]$

Tanshinon 1

Salvianolic acid A phenolic acids<smiles>O=C(/C=C/c1ccc(O)c(O)c1/C=C/c1ccc(O)c(O)c1)O[C@@H](Cc1ccc(O)c(O)c1)C(=O)O</smiles>

osteoblast differentiation modulation and osteoblast activity upregulation [24,25]
Salvianolic acid B phenolic acids

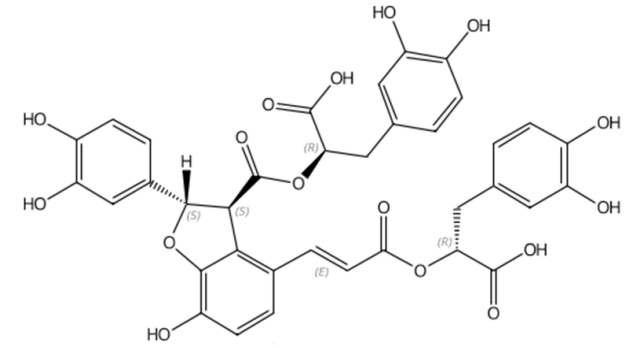

HO

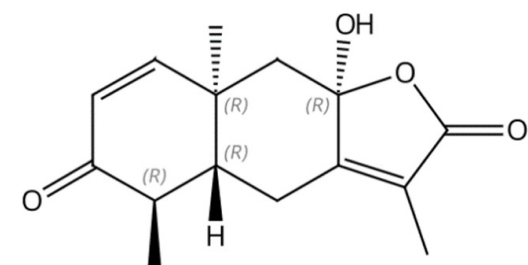

osteoblast differentiation modulation and osteoblast activity upregulation [24,25]
Eudebeiolide B

eudesmane-

type
sesquiter-
penoid


Table 2. Summary of potential anti-osteoporotic properties of botanicals in clinical trials.

\begin{tabular}{|c|c|c|c|c|}
\hline Botanicals & Population and Design & Intervention & Outcome & $\begin{array}{l}\text { Authors and } \\
\text { References }\end{array}$ \\
\hline Soy isoflavones & $\begin{array}{l}\text { single open-group prospective } \\
\text { clinical intervention; } 42 \\
\text { postmenopausal women, }\end{array}$ & $\begin{array}{l}\text { three daily servings for } 12 \\
\text { consecutive weeks of whole soy } \\
\text { foods containing approximately } \\
\quad 60 \mathrm{mg} \text { / day of isoflavones }\end{array}$ & $\downarrow$ NTX, $\uparrow$ osteocalcin & $\begin{array}{l}\text { Scheiber } 2001 \\
\text { [27] }\end{array}$ \\
\hline Soy isoflavones & $\begin{array}{l}\text { RCT with } 3 \text { groups: soy rich diet, } \\
\text { HRT, control; } 187 \text { healthy } \\
\text { asymptomatic postmenopausal } \\
\text { women aged 39-60, }\end{array}$ & $\begin{array}{l}\text { approximately } 47 \mathrm{mg} / \text { day of } \\
\text { isoflavones in diet group; } \\
\text { duration: } 6 \text { moths }\end{array}$ & $\begin{array}{l}\uparrow \text { bone osteoblastic activity but not } \\
\text { as effective as HRT in reducing the } \\
\text { postmenopausal turnover, } \uparrow \\
\text { osteocalcin }\end{array}$ & $\begin{array}{l}\text { Chiechi } 2002 \\
\text { [28] }\end{array}$ \\
\hline Soy isoflavones & $\begin{array}{l}\text { RCT with } 3 \text { groups: placebo, } \\
\text { mid-dose, and } \\
\text { high-dose, in pill form; } 203 \\
\text { postmenopausal Chinese } \\
\text { women aged } 48 \text { to } 62,\end{array}$ & $\begin{array}{l}\text { placebo (daily dose of } 0 \mathrm{mg} \\
\text { isoflavones }+500 \mathrm{mg} \text { calcium, } \\
\quad n=67) \text { mid-dose ( } 40 \mathrm{mg} \\
\text { isoflavones }+500 \mathrm{mg} \text { calcium, } \\
n=68) \text { and high-dose }(80 \mathrm{mg} \\
\text { isoflavones }+500 \mathrm{mg} \text { calcium, } \\
n=68) \text {; duration: } 12 \text { months }\end{array}$ & $\begin{array}{l}\text { favourable effect on rates of } \\
\text { change in BMC at the total hip and } \\
\text { trochanter among later } \\
\text { postmenopausal women }(>4 \mathrm{y}) \text {, in } \\
\text { women with lower body weight } \\
\text { ( } \leq \text { median, } 55.5 \mathrm{~kg}) \text {, or among } \\
\text { women with lower level of calcium } \\
\text { intake ( } \leq \text { median, } 1095 \mathrm{mg} / \text { day })\end{array}$ & Chen 2004 [29] \\
\hline Soy isoflavones & $\begin{array}{l}\text { RCT with } 3 \text { groups: placebo, } \\
\text { mid-dose, and } \\
\text { high-dose; } 90 \text { Chinese } \\
\text { postmenopausal women aged } \\
45-60\end{array}$ & $\begin{array}{l}\text { placebo (daily dose of } 0 \mathrm{mg} \\
\text { isoflavones) mid-dose }(84 \mathrm{mg}) \\
\text { and high dose (126 mg), } 30 \\
\text { subjects / group; duration: } \\
\text { 6months }\end{array}$ & $\begin{array}{l}\text { Retardation of lumbar and femoral } \\
\text { bone loss at the lumbar spine } \\
\text { (L1-L4) and bone resorption }\end{array}$ & Ye 2006 [30] \\
\hline Soy isoflavones & $\begin{array}{l}\text { double-blind RCT with } 2 \text { groups: } \\
\text { placebo, isoflavone conjugates in } \\
\text { capsule form, } 68 \\
\text { postmenopausal Japanese } \\
\text { women }\end{array}$ & $\begin{array}{c}\text { Isoflavone group (75 mg of } \\
\text { isoflavone conjugates/day), } 34 \\
\text { subjects/group; duration: } 12 \\
\text { months }\end{array}$ & $\begin{array}{l}\uparrow \text { serum equol in the equol } \\
\text { producers but not in the } \\
\text { nonproducers, preventive effects } \\
\text { of isoflavones on hip BMD }\end{array}$ & Wu 2007 [31] \\
\hline Soy isoflavones & $\begin{array}{l}\text { double-blind RCT with } 3 \text { groups: } \\
\text { placebo, mid-dose, and } \\
\text { high-dose in tablet form; } 255 \\
\text { postmenopausal women aged } \\
46-63\end{array}$ & $\begin{array}{c}\text { placebo (daily dose of } 0 \mathrm{mg} \\
\text { isoflavones) mid-dose }(80 \mathrm{mg}) \\
\text { and high dose }(120 \mathrm{mg}) \\
\text { duration: } 3 \text { years }\end{array}$ & $\begin{array}{l}\text { mild beneficial femoral BMD_-and } \\
\text { SSI }\end{array}$ & $\begin{array}{l}\text { Shedd-Wise } \\
2011[32]\end{array}$ \\
\hline Soy isoflavones & $\begin{array}{l}\text { double-blind RCT with } 2 \text { groups: } \\
\text { placebo, isoflavones in tablet } \\
\text { form; } 87 \text { Korean postmenopausal } \\
\text { women aged } 45-60\end{array}$ & $\begin{array}{l}\text { Isoflavone group = } 70 \mathrm{mg} \text { in } 2 \\
\text { tablet per day ( } 8.0 \mathrm{mg} \text { glycitin, } \\
20 \mathrm{mg} \text { daidzein, and } 12.4 \mathrm{mg} \\
\text { genistin); duration: } 12 \text { weeks }\end{array}$ & $\uparrow$ serum BALP and osteocalcin & Lee 2017 [33] \\
\hline Soy isoflavones & $\begin{array}{l}\text { RCT with } 3 \text { groups; placebo, } \\
\text { HRT, phytoestrogens; } 325 \\
\text { postmenopausal women }\end{array}$ & $\begin{array}{l}\text { HRT group ( } 1 \mathrm{mg} \text { oestradiol and } \\
0.5 \text { mg norethisterone acetate p.o. } \\
\text { daily, phytoestrogens group } \\
(40 \% \text { standardized extract with } \\
20 \text { mg soy isoflavones (genistein } \\
\text { and daidzein), two capsules = } 40 \\
\text { mg p.o. daily; duration: } 12 \\
\text { months }\end{array}$ & $\begin{array}{l}\text { no significant differences between } \\
\text { the effectiveness of the HRT and } \\
\text { phytoestrogen in terms of effects } \\
\text { on BMD and bone resorption }\end{array}$ & Tit 2018 [34] \\
\hline Soy isoflavones & $\begin{array}{l}\text { double-blind RCT with } 3 \text { groups: } \\
\text { placebo, soy protein, soy protein } \\
\text { + isoflavone in snack bar; } 200 \\
\text { women within } 2 \text { years of the } \\
\text { onset of their menopause }\end{array}$ & $\begin{array}{l}\text { placebo (isoflavone of less than } \\
300 \text { parts per billion) PI ( } 15 \mathrm{~g} \text { soy } \\
\text { protein with } 66 \mathrm{mg} \text { of } \\
\text { isoflavones), SP ( } 15 \mathrm{~g} \text { soy protein } \\
\text { alone, isoflavone free) daily, } 100 \\
\text { women/group; } \\
\text { duration: } 6 \text { months }\end{array}$ & $\begin{array}{c}\downarrow \text { CTX with SPI supplementation } \\
\text { compared to SP, } \downarrow \text { P1NP with SPI } \\
\text { supplementation }\end{array}$ & $\begin{array}{l}\text { Sathyapalan } \\
2017[35]\end{array}$ \\
\hline Soy isoflavones & $\begin{array}{c}\text { double-blind RCT with } 2 \text { groups: } \\
\text { placebo, isoflavones in form of } \\
\text { tablet }\end{array}$ & $\begin{array}{l}\text { placebo ( } 0 \text { mg of isoflavones), } \\
\text { isoflavones extracted from soy } \\
\text { protein ( } 200 \mathrm{mg} \text { daily }=4 \text { tablets }) \\
248 \text { multi-ethnic menopausal } \\
\text { women aged } 45 \text { to } 60 \text {; duration: } \\
2 \text { years }\end{array}$ & $\begin{array}{l}\text { not superior to placebo in } \\
\text { preventing bone loss or in } \\
\text { reducing bone turnover or } \\
\text { menopausal symptoms in women } \\
\text { in the first } 5 \text { years of menopause }\end{array}$ & Levis 2011 [36] \\
\hline Soy isoflavones & $\begin{array}{l}\text { double-blind RCT with } 2 \text { groups: } \\
\text { placebo, phytoestrogens; } 202 \\
\text { postmenopausal women aged } \\
60-75\end{array}$ & $\begin{array}{c}\text { placebo (milk protein), } \\
\text { phytoestrogens ( } 25.6 \mathrm{~g} \text { soy } \\
\text { protein containing } 52 \mathrm{mg} \\
\text { genistein, } 41 \mathrm{mg} \text { daidzein and } 6 \\
\text { mg glycetein (aglycone weights; } \\
\text { duration: } 12 \text { months }\end{array}$ & $\begin{array}{l}\text { no significant differences for BALP, } \\
\text { calcium, and phosphorus } \\
\text { measurements. }\end{array}$ & $\begin{array}{c}\text { Kreijkamp- } \\
\text { Kaspers } 2004 \\
{[37]}\end{array}$ \\
\hline
\end{tabular}


Table 2. Cont.

\begin{tabular}{|c|c|c|c|c|}
\hline Botanicals & Population and Design & Intervention & Outcome & $\begin{array}{l}\text { Authors and } \\
\text { References }\end{array}$ \\
\hline Soy isoflavones & $\begin{array}{l}\text { double-blind, multicentre RCT } \\
\text { with } 2 \text { groups: } \\
\text { isoflavone-enriched biscuits and } \\
\text { bars and control biscuits and } \\
\text { bars; } 237 \text { early postmenopausal } \\
\text { women aged } 53 \pm 3 y\end{array}$ & $\begin{array}{c}\text { placebo group (biscuits and } \\
\text { cereal bar), isoflavone- enriched } \\
\text { foods (soy isoflavone } \\
\text { concentrate containing } 40-50 \% \\
\text { of isoflavones) providing a mean } \\
\text { daily intake of } 110 \mathrm{mg} \text { isoflavone } \\
\text { aglycones/day; duration: } 12 \\
\text { months }\end{array}$ & $\begin{array}{l}\text { isoflavone-enriched products did } \\
\text { not alter lumbar and total body } \\
\text { BMD or markers of bone } \\
\text { formation and bone resorption }\end{array}$ & Brink 2008 [38] \\
\hline Genistein & $\begin{array}{l}\text { double-blind RCT with } 2 \text { groups: } \\
\text { placebo, genistein; } \\
389 \text { postmenopausal women }\end{array}$ & $\begin{array}{l}\text { placebo group (calcium and } \\
\text { vitamin } \mathrm{D}, n=191) \text {, genistein } \\
\text { aglycone group ( } 54 \mathrm{mg} / \text { day }+ \\
\text { calcium and vitamin } \mathrm{D}, n=198 \text { ) } \\
\text { duration: } 36 \text { months }\end{array}$ & $\begin{array}{l}\uparrow \text { lumbar and femoral BMD, } \downarrow \text { bone } \\
\text { resorption markers (DPD, CTX, } \\
\text { RANKL), } \uparrow \text { bone formation } \\
\text { markers (BALP, IGF- } 1 \text { and OPG) }\end{array}$ & $\begin{array}{l}\text { Marini } 2007 \\
\text { [39]; Marini } \\
\text { 2008 [40] }\end{array}$ \\
\hline Genistein & $\begin{array}{l}\text { double-blind RCT with } 2 \text { groups: } \\
\text { placebo, genistein; } \\
138 \text { postmenopausal women } \\
\text { (age } 49-67 \text { years) }\end{array}$ & $\begin{array}{l}\text { placebo (0mg of isoflavones, } \\
n=67) \text {, genistein }(54 \mathrm{mg} / \text { day, } \\
n=71) \text {, duration: } 24 \text { months }\end{array}$ & $\begin{array}{c}\uparrow \text { femoral and lumbar BMD, } \\
\text { improvement of the quantitative } \\
\text { ultrasound parameters (stiffness } \\
\text { index, amplitude-dependent speed } \\
\text { of sound, and bone transmission } \\
\text { time) }\end{array}$ & $\begin{array}{c}\text { Atteritano } 2009 \\
{[41]}\end{array}$ \\
\hline Genistein & $\begin{array}{l}\text { double-blind RCT with } 2 \text { groups: } \\
\text { placebo, geniVida } \\
\text { group; } 70 \text { postmene blend } \\
\text { women }\end{array}$ & $\begin{array}{c}\text { placebo (calcium only, } n=28) \\
\text { genistein group }=30 \\
\text { mg/daygenistein + vitamin D3 } \\
(800 \text { IU/days }+ \text { vitamin K1 }(150 \\
\mu \mathrm{g} / \text { days })+ \text { polyunsaturated } \\
\text { fatty acids }(1 \text { g polyunsaturated } \\
\text { fatty acids as ethyl ester: } \\
\text { eicosapentaenoic } \\
\text { acid / docosahexaenoic acid ratio } \\
=\sim 2 / 1, n=30) ; \\
\text { duration: } 6 \text { months }\end{array}$ & $\uparrow \mathrm{BMD}, \uparrow \mathrm{BALP}$ and NTX & Lappe 2013 [42] \\
\hline Genistein & $\begin{array}{l}\text { double-blind RCT with } 2 \text { groups: } \\
\text { placebo, genistein, } 121 \\
\text { postmenopausal women }\end{array}$ & $\begin{array}{l}\text { placebo (1000 mg of calcium and } \\
800 \text { IU vitamin D3; } n=59) \\
\text { genistein aglycone group ( } 54 \\
\text { mg/day + calcium, vitamin D3; } \\
n=62 \text {, duration: } 24 \text { months }\end{array}$ & $\begin{array}{l}\uparrow \text { femoral and lumbar BMD, } \uparrow \\
\text { BALP }\end{array}$ & $\begin{array}{c}\text { Arcoraci } 2017 \\
\text { [43] }\end{array}$ \\
\hline $\begin{array}{l}\text { Red clover } \\
\text { isoflavones } \\
\text { (genistein, } \\
\text { daidzein, } \\
\text { formononetin, } \\
\text { biochanin A) }\end{array}$ & $\begin{array}{l}\text { double-blind RCT with } 4 \text { groups: } \\
\text { placebo, red clover isoflavone } \\
\text { preparation (Rimostil) in } 3 \text { doses, } \\
46 \text { postmenopausal women }\end{array}$ & $\begin{array}{c}\text { placebo, Rimostil } \\
\text { (phytoestrogens) - } 28.5 \mathrm{mg}, 57 \\
\text { mg, or } 85.5 \mathrm{mg} / \text { day, duration: } 6 \\
\text { months, }\end{array}$ & $\begin{array}{c}\uparrow \text { BMD after } 57 \text { mg and } 85.5 \\
\text { mg/day }\end{array}$ & $\begin{array}{l}\text { Clifton-Bligh } \\
2001 \text { [44] }\end{array}$ \\
\hline $\begin{array}{l}\text { Red clover } \\
\text { isoflavones }\end{array}$ & $\begin{array}{l}\text { double-blind RCT with } 2 \text { groups: } \\
\text { placebo, isoflavone supplement } \\
\text { Promensil }{ }^{\circledR} ; 205 \text { pre-, peri-, and } \\
\text { postmenopausal women aged } \\
49-65\end{array}$ & $\begin{array}{c}\text { placebo, isoflavone supplement } \\
\text { (providing } 26 \mathrm{mg} \text { biochanin } \mathrm{A}, \\
16 \mathrm{mg} \text { formononetin, } 1 \mathrm{mg} \\
\text { genistein, } 0.5 \mathrm{mg} \\
\text { daidzein/daily); duration: } 12 \\
\text { months }\end{array}$ & $\begin{array}{c}\uparrow \text { bone formation markers (BALP, } \\
\text { P1NP), } \downarrow \text { lumbar spine BMC and } \\
\text { BMD }\end{array}$ & $\begin{array}{c}\text { Akinson } 2004 \\
{[45]}\end{array}$ \\
\hline $\begin{array}{l}\text { Red clover } \\
\text { isoflavones }\end{array}$ & $\begin{array}{l}\text { double-blind, parallel RCT with } \\
2 \text { groups: placebo, red clover } \\
\text { extract; } 78 \text { postmenopausal } \\
\text { osteopenic women } \\
\text { supplemented with calcium } 1200 \\
\text { mg/day, magnesium } 550 \\
\text { mg/day, calcitriol } 25 \mu \mathrm{g} / \text { day }\end{array}$ & $\begin{array}{l}\text { placebo, red clover extract }(60 \\
\text { mg isoflavone aglycones/day }+ \\
\text { probiotics); duration: } 12 \text { months }\end{array}$ & $\begin{array}{l}\downarrow \text { lumbar and femoral BMD loss, } \downarrow \\
\text { CTX }\end{array}$ & $\begin{array}{c}\text { Lambert } 2017 \\
{[46]}\end{array}$ \\
\hline $\begin{array}{l}\text { Red clover } \\
\text { isoflavones }\end{array}$ & $\begin{array}{l}\text { double-blind RCT with } 2 \text { groups: } \\
\text { placebo, red clover extract; } 60 \\
\text { menopausal women }\end{array}$ & $\begin{array}{l}\text { placebo, red clover extract (daily } \\
\text { dose of } 150 \mathrm{~mL} \text { containing } 37.1 \\
\text { mg isoflavones }=33.8 \mathrm{mg} \text { as } \\
\text { aglycones); duration: } 12 \text { weeks }\end{array}$ & $\uparrow$ spinal BMD & Thorup 2015 \\
\hline $\begin{array}{l}\text { Red clover } \\
\text { isoflavones }\end{array}$ & $\begin{array}{l}\text { double-blind RCT with } 2 \text { groups: } \\
\text { placebo, standardized red clover } \\
\text { isoflavone dietary supplement } \\
\text { (Promensil }{ }^{\circledR} \text { ); } 401 \text { healthy } \\
\text { women aged 35-70 years }\end{array}$ & $\begin{array}{l}\text { Placebo, red clover isoflavones } \\
\text { (40 mg/day); } \\
\text { duration: } 36 \text { months }\end{array}$ & $\begin{array}{l}\text { safe and well tolerated but no } \\
\text { effect on BMD }\end{array}$ & $\begin{array}{l}\text { Powles } 2008 \\
\quad[48]\end{array}$ \\
\hline
\end{tabular}


Table 2. Cont.

\begin{tabular}{|c|c|c|c|c|}
\hline Botanicals & Population and Design & Intervention & Outcome & $\begin{array}{l}\text { Authors and } \\
\text { References }\end{array}$ \\
\hline $\begin{array}{l}\text { Red clover } \\
\text { isoflavones }\end{array}$ & $\begin{array}{l}\text { double-blind RCT with } 3 \text { groups: } \\
\text { placebo and } 2 \text { dietary } \\
\text { supplements derived from red } \\
\text { clover, } 252 \text { menopausal women } \\
\text { ages } 45-60 \text { years }\end{array}$ & $\begin{array}{c}\text { placebo, Promensil }{ }^{\circledR}(82 \mathrm{mg} \text { total } \\
\text { isoflavones), Rimostil }{ }^{\circledR}(57.2 \mathrm{mg} \\
\text { total isoflavones), duration: } 12 \\
\text { weeks }\end{array}$ & $\begin{array}{l}\text { no effect on bone turnover } \\
\text { markers. }\end{array}$ & $\begin{array}{l}\text { Knudson Schult } \\
\text { 2004 [49] }\end{array}$ \\
\hline $\begin{array}{l}\text { Kudzu root } \\
\text { (Pueraria } \\
\text { candollei var. } \\
\quad \text { mirifica) }\end{array}$ & $\begin{array}{l}\text { double-blind RCT with } 4 \text { groups: } \\
\text { placebo, } 3 \text { dose of Pueraria; } 71 \\
\text { postmenopausal women aged } 45 \\
\text { to } 60 \text { years }\end{array}$ & $\begin{array}{l}\text { placebo }(n=20) \text {, Pueraria } \\
\text { mirifica in capsules }(20,30 \text {, or } 50 \\
\text { mg once daily, } n=51) \text {; duration: } \\
\qquad 24 \text { weeks }\end{array}$ & $\downarrow$ BALP & $\begin{array}{c}\text { Manonai } 2008 \\
{[50]}\end{array}$ \\
\hline $\begin{array}{l}\text { Kudzu root } \\
\text { (Pueraria } \\
\text { candollei var. } \\
\text { mirifica) }\end{array}$ & $\begin{array}{l}\text { double-blind RCT with } 2 \text { groups } \\
19 \text { postmenopausal women }\end{array}$ & $\begin{array}{l}\text { placebo tablet, tablet containing } \\
25 \text { mg dried PM root powder, } 4 \\
\text { tablets/day; duration: } 2 \text { months }\end{array}$ & $\downarrow$ ALP & $\begin{array}{c}\text { Okamura } 2008 \\
{[51]}\end{array}$ \\
\hline Epimedium & $\begin{array}{l}\text { double-blind RCT with } 2 \text { groups: } \\
\text { placebo, Epimedium-derived } \\
\text { phytoestrogen flavonoids (EPF), } \\
100 \text { healthy late postmenopausal } \\
\text { women }\end{array}$ & $\begin{array}{l}\text { placebo }(n=50) \text {, EPF group }(n= \\
50 ; \text { a daily dose of } 60 \mathrm{mg} \text { Icariin, } \\
15 \mathrm{mg} \text { daidzein, and } 3 \mathrm{mg} \\
\text { genistein }),+300 \mathrm{mg} \text { calcium } \\
\text { daily for both group; duration: } \\
24 \text { months }\end{array}$ & $\begin{array}{c}\uparrow \text { lumbar and femoral BMD, } \downarrow \\
\text { DPD, }\end{array}$ & Zang 2007 [52] \\
\hline Dried plums & $\begin{array}{l}\text { RCT with } 2 \text { groups: placebo } \\
\text { (dried apples), dried plums; } 58 \\
\text { postmenopausal women }\end{array}$ & $\begin{array}{c}\text { placebo (dried apples } 75 \text { g daily), } \\
\text { dried plums (100 g daily); } \\
\text { duration: } 3 \text { months }\end{array}$ & $\uparrow \mathrm{IGF}-1, \uparrow \mathrm{ALP}, \uparrow \mathrm{BALP}$ & Ajamandi 2002 \\
\hline Dried plums & $\begin{array}{l}\text { RCT with } 2 \text { groups: placebo, } \\
\text { dried plums, } 160 \\
\text { postmenopausal women } \\
\text { with osteopenia }\end{array}$ & $\begin{array}{l}\text { placebo (dried apples } 75 \text { g daily), } \\
\text { dried plums (100 g daily) + 500 } \\
\text { mg Calcium, } 400 \text { IU }(10 \mu \mathrm{g}) \\
\text { vitamin D daily for both group; } \\
\text { duration: } 12 \text { months }\end{array}$ & $\uparrow$ ulnar and lumbar BMD, $\downarrow$ BALP & $\begin{array}{l}\text { Hooshmand } \\
2011[54]\end{array}$ \\
\hline Dried plums & $\begin{array}{l}\text { RCT with } 3 \text { groups: placebo, } 2 \\
\text { dose of dried plums, } 48 \text { older } \\
\text { postmenopausal women }\end{array}$ & $\begin{array}{l}\text { control (0 g/day dried plum), } \\
\text { dried plum ( } 50 \text { or } 100 \mathrm{~g} / \text { day } \\
\text { dried plum), duration: } 6 \text { months }\end{array}$ & $\begin{array}{l}\uparrow \mathrm{BMD}, \downarrow \text { TRAP-5b, } \uparrow \\
\text { BALP } / \text { TRAP-5b ratio }\end{array}$ & $\begin{array}{l}\text { Hooshmand } \\
2016[55]\end{array}$ \\
\hline Dried plums & $\begin{array}{l}\text { RCT with } 3 \text { groups: placebo, } 2 \\
\text { dose of dried plums; } 35 \text { men } \\
\text { between the ages of } 55 \text { and } 80 \\
\text { with moderate bone loss }\end{array}$ & $\begin{array}{l}\text { control group ( } 0 \mathrm{~g} \text { prunes), } 100 \mathrm{~g} \\
\text { prunes daily, } 50 \mathrm{~g} \text { prunes daily, }+ \\
\text { multivitamin containing } 450 \mathrm{mg} \\
\text { calcium and } 800 \mathrm{IU} \text { vitamin D } \\
\text { for all group, duration: } 3 \text { months }\end{array}$ & $\begin{array}{c}\downarrow \text { osteocalcin, } \uparrow \text { OPG } / \text { RANKL } \\
\text { ratio }\end{array}$ & Ajmandi 2020 \\
\hline $\begin{array}{l}\text { Horsetail } \\
\text { (Equisetum } \\
\text { arvense) }\end{array}$ & $\begin{array}{c}\text { Double blind RCT with } 4 \text { groups: } \\
\text { control, placebo + horsetail } \\
\text { extract, horsetail extract, calcium, } \\
122 \text { women in menopause for at } \\
\text { least two years }\end{array}$ & $\begin{array}{l}\text { no treatment / control group ( } n= \\
29) \text {, placebo for } 40 \text { days and } \\
\text { titrated horsetail extract for a } \\
\text { further } 40 \text { days }(n=31) \text {, titrated } \\
\text { dry horsetail extract for } 80 \text { days } \\
(n=30) \text {; Calcium }\left(\text { Osteosil }{ }^{\circledR}\right) \text { for } \\
80 \text { days }(n=32) \text {, After the } 80 \text {-day } \\
\text { initial study period, patients } \\
\text { treated with titrated horsetail } \\
\text { extract and with calcium } \\
\text { continued treatment for one year }\end{array}$ & $\begin{array}{c}\uparrow \text { in the average densitometric } \\
\text { values for the vertebra }\end{array}$ & $\begin{array}{l}\text { Corletto } 1999 \\
\text { [57] }\end{array}$ \\
\hline $\begin{array}{l}\text { Black cohosh } \\
\text { (Cimcifuga } \\
\text { racemosa) }\end{array}$ & $\begin{array}{c}\text { double-blind RCT with } 3 \text { groups: } \\
\text { placebo, black cohosh, } \\
\text { oestrogens; } 62 \text { postmenopausal } \\
\text { women }\end{array}$ & $\begin{array}{c}\text { placebo, black cohosh ( } 40 \mathrm{mg} \text { of } \\
\text { herbal drug/day), conjugated } \\
\text { oestrogens ( } 0.6 \mathrm{mg} / \text { day); } \\
\text { duration: } 12 \text { weeks. }\end{array}$ & $\begin{array}{l}\uparrow \text { osteoblast activity, weak } \\
\text { estrogen-like activity, no } \\
\text { significant effects on coagulation } \\
\text { markers and liver enzymes }\end{array}$ & $\begin{array}{l}\text { Wuttke } 2006 \\
\text { [58] }\end{array}$ \\
\hline $\begin{array}{l}\text { Black cohosh } \\
\text { (Cimcifuga } \\
\text { racemosa) }\end{array}$ & $\begin{array}{l}\text { prospective clinical trial with } 2 \\
\text { groups: untreated control, } \\
\text { isopropanolic extract of } \\
\text { Cimicifuga racemosa, } 82 \\
\text { postmenopausal women }\end{array}$ & $\begin{array}{c}\text { control group }(n=37), \\
\text { isopropanolic extract of } \\
\text { Cimicifuga racemosa (Remifemin }{ }^{\circledR}, \\
40 \text { mg/day, } n=45) \text {, duration: } 3 \\
\text { months }\end{array}$ & $\begin{array}{l}\downarrow \text { NTX (marker of bone resorption), } \\
\uparrow \text { ALP (marker of bone formation) }\end{array}$ & $\begin{array}{l}\text { Garcia-Pérez } \\
2009 \text { [59] }\end{array}$ \\
\hline $\begin{array}{l}\text { Black cohosh } \\
\text { (Cimcifuga } \\
\text { racemosa) }\end{array}$ & $\begin{array}{l}\text { RCT with } 3 \text { groups: control (CG), } \\
\text { exercise group (EG), exercise and } \\
\text { Cimicifuga racemosa (CR) } \\
\text { supplementation group (EGCR), } \\
128 \text { early postmenopausal } \\
\text { women }\end{array}$ & $\begin{array}{l}\text { CG (wellness control, } n=42), \text { EG } \\
(n=43), \text { EGCR }(40 \mathrm{mg} / \text { day of } \\
\text { CR BNO } 1055 ; n=43), \text { Calcium } \\
(1500 \mathrm{mg} / \mathrm{d})+\text { vitamin D }(500 \\
\text { IE/d) supplementation for all } \\
\text { participant duration:12 months }\end{array}$ & $\begin{array}{c}\text { CR (CR BNO 1055) did not } \\
\text { enhance positive effects of exercise } \\
\text { on BMD at the lumbar spine }\end{array}$ & $\begin{array}{l}\text { Bebenek } 2010 \\
{[60]}\end{array}$ \\
\hline
\end{tabular}


Table 2. Cont.

\begin{tabular}{|c|c|c|c|c|}
\hline Botanicals & Population and Design & Intervention & Outcome & $\begin{array}{l}\text { Authors and } \\
\text { References }\end{array}$ \\
\hline $\begin{array}{l}\text { Labisia pumila } \\
\text { and Eurycoma } \\
\text { longifolia }\end{array}$ & $\begin{array}{l}\text { double-blind RCT with } 2 \text { groups: } \\
\text { placebo, Nu-femme }{ }^{\mathrm{TM}}, 119 \\
\text { healthy women aged } 41-55 \text { years } \\
\text { experiencing peri-menopausal or } \\
\text { menopausal symptoms }\end{array}$ & $\begin{array}{c}\text { placebo }(n=59) \text {, herbal } \\
\text { formulation }\left(\mathrm{Nu}-\text {-femme }{ }^{\mathrm{TM}}, n=\right. \\
60)=200 \mathrm{mg} \text { Labisia pumila } \\
\left(\mathrm{SLP}+{ }^{\circledR}\right)+50 \mathrm{mg} \text { Eurycoma } \\
\text { longifolia }\left(\text { Physta }{ }^{\circledR}\right) ; \text { duration: } \\
\text { 24 weeks }\end{array}$ & $\begin{array}{l}\text { No significant effect on bone } \\
\text { formation (BALP) and resorption } \\
\text { (NTX) markers }\end{array}$ & $\begin{array}{c}\text { Chinnappan } \\
2020 \text { [61] }\end{array}$ \\
\hline
\end{tabular}

ALP—alkaline phosphatase, BALP—bone-specific alkaline phosphatase, BMC—bone mineral content, BMD—bone mineral density, CTX - type I collagen crosslinked beta C-telopeptide, DPD—deoxypyridinoline, HRT-hormonal replacement therapy, IGF-1-insulin-like growth factor 1, NTX-type I collagen crosslinked N- telopeptide, OPG-osteoprotegerin, P1NP-type I procollagen-N-propeptide, RANKL—Receptor Activator for Nuclear Factor kB Ligand, SSI—strength strain index, $\uparrow$ —increased, $\downarrow$ —ecreased

\section{Phytoestrogens}

Phytoestrogens are naturally occurring nonsteroidal plant compounds that resemble oestrogens and have oestrogenic and/or antiestrogenic activity. They can be divided into two main groups: flavonoids and non-flavonoids. Isoflavones, coumestans, and prenylflavonoids belong to flavonoids, and lignans belong to non-flavonoids [62].

\subsection{Isoflavones}

Isoflavones are phenolic compounds that belong to the most estrogenic plant-derived substances. Their chemical structure is similar to that of oestradiol. They include, among others, genistein, daidzein, glycitein, biochanin A, and formononetin (Table 3). The main source of isoflavones are legumes belonging to Fabaceae: soybean (Glycine max) as a source of genistein, daidzein, and glycitein, and red clover (Trifolium pratense) as a source of biochanin $\mathrm{A}$ and formononetin [62]. In the group of plants containing isoflavones, there are also alfalfa (Medicago saltiva L.), beans (green bean, mung bean), psoralea (Psoralea corylifolia) and kudzu root (Pueraria lobata L.) [14]. In the human gastrointestinal tract formononetin, contained in dietary supplements based on red clover, is transformed to daidzein [63]. The amount of isoflavones in soybeans ranges from 1.2 to $4.2 \mathrm{mg}$ per $\mathrm{g}$ of dry weight, whereas in red clover, it ranges from 10 to $25 \mathrm{mg}$ per $\mathrm{g}$ of dry weight [14]. Isoflavones exert the biologic effect due to two different mechanisms. On the one hand, they act through the classical oestrogen receptor (ER)-mediated signalling pathway, but additionally, it has been described that they may activate intracellular pathways such as protein tyrosine kinase, phospholipase C and MAPK [14]. As most isoflavones are ER $\beta$-selective ligands, it can be supposed that they selectively target bone cells without having an undesired influence on other oestrogen-sensitive tissues, such as the breast and the uterus.

Table 3. Four chemical forms of main isoflavones.

\begin{tabular}{cccc}
\hline Aglycones & Glycosides & Acetylglycosides & $\begin{array}{c}\text { Malonyl Isoflavone } \\
\text { Glycosides }\end{array}$ \\
\hline Daidzein & Daidzin & Acetyldaidzin & Malonyldaidzin \\
Genistein & Genistin & Acetylgenistin & Malonylgenistin \\
Glycitein & Glycitin & Acetylglycitin & Malonylglycitin \\
Biochanin A & Sissostrin & & Malonylsissostrin \\
Formononetin & Ononin & Malonylononin \\
Daidzein & Daidzin & Acetyldaidzin & Malonyldaidzin \\
\hline
\end{tabular}

\subsubsection{Soybean in Clinical Trials}

The soybean (Glycine max L.) is an annual plant belonging to the Fabaceae family, which grows mainly in Southwest Asia. It is a rich source of proteins and flavonoids, such as genistein, daidzein, biochanin A, and glycitein [64]. In soybean, the aglycones and conjugate forms of genistein account for $60 \%$ of isoflavones and daidzein for up to $30 \%$ [65]. 
Epidemiological studies have shown that the consumption of food that contains soy may reduce the risk of fracture in postmenopausal women, particularly among those in the early years following menopause [66]. Authors of several observational studies have noticed that populations with a high intake of soy are characterized with a lower incidence of osteoporotic fractures than Western populations $[67,68]$.

To date, many clinical trials (Table 2), systematic reviews, and meta-analyses have been carried out on this topic. Their results suggest that soy phytoestrogens exert significant effects on bone metabolism, and that they inhibit, to some degree, osteoporosis in postmenopausal women [64]. In a study by Scheiber et al., administration of soy isoflavone (60 mg/day) during 12 consecutive weeks increased serum levels of phytoestrogens and ameliorated several key clinical risk factors for osteoporosis in healthy postmenopausal women [27]. Chiechi et al. have showed that supplementation with soya isoflavone in 2 meals twice a week increased bone osteoblastic activity and the serum osteocalcin level [28]. The 12-month-long administration of soy isoflavones ( $40 \mathrm{mg}$ or $80 \mathrm{mg}$ ) maintained hip bone mineral content in later menopause or those with lower body weight or calcium [29]. In another clinical trial, it was reported that isoflavones (126 mg for 6 months) reduced bone loss [30]. The authors suggested that the observed beneficial effect was due to the inhibition of bone resorption in non-obese postmenopausal Chinese women. Similar findings were reported by Wu et al. after supplementation of early postmenopausal women with $75 \mathrm{mg}$ of isoflavone conjugates/day for 1 year [31]. Increased volumetric bone mineral density (vBMD) in postmenopausal women was observed after taking a tablet with isoflavones 80 or $120 \mathrm{mg}$ /day for 3 years [32]. An increase in serum concentrations of bone-specific alkaline phosphatase (BALP) and osteocalcin as markers of increased bone formation were caused by soya isoflavone supplementation ( $70 \mathrm{mg} /$ day for 12 weeks) in Korean postmenopausal women [33]. Tit et al. reported the similar efficacy of hormonal replacement therapy (HRT) and phytoestrogens in terms of the effects on BMD and bone resorption in postmenopausal women. Two capsules with $40 \%$ standardized extract $(20 \mathrm{mg}$ soy isoflavones genistein and daidzein per capsule) given orally for 1 year significantly reduced bone resorption [34]. In a randomized clinical trial (RCT) with women during early menopause, Sathyapalan et al. compared the administration of $15 \mathrm{~g}$ soy protein with $66 \mathrm{mg}$ isoflavone or $15 \mathrm{~g}$ soy protein alone. Moreover, a 6-month long observation revealed that soy reduced bone turnover markers, i.e., type I collagen crosslinked beta C-telopeptide (CTX, bone resorption marker) and type I procollagen-N-propeptide (P1NP, bone formation marker) [35]. However, the results are not consistent, with the study of Levis et al. reporting that supplementation with $200 \mathrm{mg}$ of soy isoflavones daily for 2 years did not protect menopausal women against bone loss [36]. Kreijkamp-Kaspers et al. obtained convergent results-BMD did not differ significantly after the $99 \mathrm{mg}$ supplementation of isoflavones in $25.6 \mathrm{~g}$ of soy protein for one year in postmenopausal women [37]. Similarly, another study indicated that the $110 \mathrm{mg} /$ day of soy isoflavone aglycone given for one year in postmenopausal women did not prevent postmenopausal bone loss or affected bone turnover [38].

Phytoestrogen genistein given in the dose $54 \mathrm{mg}$ daily for 1-3 years had positive effects on bone formation and osteopenia in postmenopausal women in several clinical trials [39-41,69]. According to a randomized, placebo-controlled, double-blind study reported by Lappe et al., a lower dose of genistein administered for a shorter time (30 mg daily for 6 months) also prevented osteoporosis development and reduced fracture risk in postmenopausal women [42]. Pawlowski et al. showed that isoflavones mixed in their natural ratios were more effective than genistein-rich soy supplement as bone-preserving agents in postmenopausal women treated for 50 days [70]. Moreover, genistein aglycone in tablets (54 mg daily for 2 years) exerted beneficial effects, not only in postmenopausal osteopenia, but also in women with osteoporosis [43].

The studies mentioned above show that isoflavones ameliorate menopause associated imbalance in bone turnover, protecting BMD and bone strength. These findings suggest that soybean phytoestrogens could be used as a dietary supplement to prevent 
postmenopausal osteoporosis. Meta-analysis of $63 \mathrm{RCTs}$ found that genistein ( $54 \mathrm{mg} /$ day) and ipriflavone $(600 \mathrm{mg} /$ day) in particular, have beneficial effects on BMD outcomes and are safe in postmenopausal women. Therefore, they may be considered as a complementary or alternative therapy and the prophylaxis of menopause-related osteoporosis [15]. Another meta-analysis of 26 randomized controlled trials ( 2652 oestrogen-deficient women) found that isoflavones attenuated moderately menopause-associated bone loss in the lumbar spine, femoral neck and distal radius [71]. Additionally, the authors noted that the effect of isoflavones on bone was greater if they were administered as aglycons. The protective influence of soy isoflavones (40-300 mg/day) on osteoporosis-related bone loss and bone mineral density in the femur, neck, lumbar spine and hip was also found in the meta-analysis of 52 controlled trials (5313 patients) [72]. However, the effectiveness of soy isoflavone supplementation in treatment and prophylaxis of osteoporosis in periand postmenopausal females remain debatable. In a systematic review of nine studies (1379 women), Perna et al. found no consensus regarding the protective effect of soy isoflavones (20-80 mg/day) on bone loss. However, the authors did not exclude the possible protective effect of soy isoflavones on bone metabolism. Similar conclusions of a systematic review of 23 clinical trials were reported by other authors that found only a minimal effect of isoflavones on bone mineral density in menopausal women [73]. Several other meta-analyses reported that the effects were minimal $[43,74,75]$ or none, as mentioned above [36]. The antiosteoporotic effects of flavonoids seem to depend on the balance between their estrogenic agonist and antagonist properties [76]. Their beneficial influence on bone metabolism may also be derived from their other biochemical properties, including enzymatic inhibition of certain protein kinases or activation of estrogen type I receptors [64]. Some authors indicate that equol—an isoflavandiol produced by gut microflora from daidzein and possessing a higher estrogenic activity than the predominant flavonoids - may be responsible for the clinical effectiveness of flavonoids [77]. The discrepancies between the results of the reported studies may also be attributed to differences in the study design.

\subsubsection{Red Clover in Clinical Trials}

Red clover (Trifolium pratense L.) belongs to the legume family and is often used to relieve symptoms of menopause, high cholesterol, and osteoporosis [78]. Isoflavones: biochanin $\mathrm{A}$, formononetin, and sissotrin, are responsible for its estrogenic activity. In intestines, biochanin A and formononetin are demethylated and metabolized to genistein and daidzein [79]. The bone-preserving effects of red clover have also been examined, but not as extensively as those of soy [80].

In a randomized, placebo-controlled study, an isoflavone preparation (Rimostil $\left.{ }^{\circledR}\right)$ containing genistein, daidzein, formononetin and biochanin A was administered to 46 postmenopausal women in a double-blind protocol after a single-blind placebo phase, and followed by a single-blind washout phase. A 6-month-long administration of an isoflavone combination extracted from red clover $(57 \mathrm{mg} /$ day or $85.5 \mathrm{mg} /$ day) to postmenopausal females increased the BMD of radius and ulna [44]. In another clinical trial $(n=205)$, the red clover extract containing $41 \mathrm{mg}$ isoflavone per tablet (Promensi ${ }^{\circledR}$ ) ameliorated the decrease of bone mineral content (BMC) and BMD in lumbar spine in pre-, peri-, and postmenopausal women taking the supplement for 12 months. Authors also reported the elevation of bone formation markers [45].

In another 12-month, double-blind, parallel design RCT, 78 postmenopausal osteopenic women were supplemented with calcium (1200 mg/day), magnesium $(550 \mathrm{mg} /$ day), calcitriol ( $25 \mathrm{mg}$ /day) and given either red clover extracts rich in isoflavone aglycones and probiotics (RCE, $60 \mathrm{mg}$ isoflavone aglycones/day and probiotics) or a masked placebo. RCE intake combined with supplementation (calcium, magnesium, and calcitriol) was more effective than supplementation alone. Twice daily RCE intake over one year prevented a menopause-associated decrease of BMD normalizing bone turnover, promoting a 
favourable oestrogen metabolite profile (2-OH:16 $\alpha-\mathrm{OH})$, and stimulating equal production in postmenopausal women with osteopenia [46].

Thorup et al. found that the intake of $150 \mathrm{~mL}$ red clover extract containing $37.1 \mathrm{mg}$ isoflavones for 12 weeks improved bone health in menopausal women $(n=60)$. The conclusions were based on BMD and T-score at the lumbar spine and plasma CTX levels [47]. However, a review of the potential skeletal benefit of red clover concluded that there was limited evidence of efficacy [81]. For example, in a placebo-controlled 3-year trial in 401 women with a family history of breast cancer, $40 \mathrm{mg}$ of red clover produced no effect on BMD [48].

In another study with perimenopausal women $(n=250)$, when taking two tablets per day containing red clover extract (28.6 mg or $41 \mathrm{mg}$ isoflavones) for 12 weeks, no significant differences in bone turnover markers were observed compared to placebo [49].

Although the evidence is limited, it appears that red clover isoflavones may have a beneficial effect on bone mineral density in peri- and postmenopausal women [80].

\subsubsection{Soybean and Red Clover in Animal Studies and In Vitro Models}

The studies that investigated the effects of soybean on markers of bone turnover in ovariectomized rats reported contradictory results. Park et al. reported that soybean increased serum osteocalcin levels and decreased urinary deoxypyridinoline (DPD) levels [82], while Byun et al. observed a decrease in osteocalcin and DPD levels [83]. However, other authors detected no influence of soybean on bone turnover markers in ovariectomized rats [84]. Hinton et al. reported that soybean improved whole bone and tissue level biomechanical properties in ovariectomized rats, although it did not improve the trabecular microarchitecture [84].

Soybean proteins contain a high level of phytate, which decreases calcium bioavailability [85], therefore, the investigations assessing the phytate-removed soybean proteins of bone metabolism were conducted. Phytate-removed and deamidated soybean $\beta$-conglycinin enhanced calcium absorption from the intestines in ovariectomized rats [85]. As a consequence, an increase in serum calcium level normalized PTH secretion. Suppression of ovariectomy-induced changes in bone turnover was also observed. Additionally, Akao et al. reported a reduction of bone resorption, enhanced BMD, and strengthened bone in ovariectomized rats receiving phytate-removed and deamidated soybean $\beta$-conglycinin [85]. However, the influence on trabecular BMD was less prominent than the influence of cortical BMD.

Soy isoflavones bind to ER $\beta$ that are expressed in the calcaneus but not in cortical bone [7]. This fact explains why they mainly influence the trabecular bone. In vivo, soy isoflavones through Smad's activation in osteoblasts lead to the upregulation of the expression of Runx2 and OSX that are important transcription factors involved in osteoblast differentiation and proliferation [86]. Soy isoflavones decreased RANKL levels. They increase the expression of OPG, $\beta$-catenin, and Wnt $3 \mathrm{a}$ and $7 \mathrm{~b}$ in osteoblasts. Noh et al. reported that the combination of soy isoflavone and hop prenylflavones (Soy-Hop) had a protective influence on bone in ovariectomized rats [87]. In their study, Soy-Hop administration in a dose-dependent manner reduced ovariectomy-induced elevation of osteocalcin, alkaline phosphatase (ALP), and CTX levels. It also attenuated the ovariectomy-induced expression of RANKL messenger ribonucleic acid (mRNA). A micro-computed tomography $(\mathrm{mCT})$ examination revealed reduced porosity and decreased separation between trabeculae in the femoral epiphysis in Sop-Hop receiving ovariectomized rats [87]. Kim et al. reported that dry-fermented soybean food ameliorated senile osteoporosis in the senescence-accelerated mouse prone 6 (SAMP6) model [88].

In vitro studies demonstrated that daidzein and genistein bound to RANKL within the side residues involved in RANK binding [89] prevented the formation of the complex of RANKL-RANK that activates bone resorption. Additionally, it was demonstrated that soy isoflavones increased Runx2 expression mineralisation in human osteosarcoma Saos-2 cell culture that activated osteoblasts and led to the acceleration of matrix mineralization [89]. 
Genistein was also shown to be able to elevate ALP activity and decrease RANKL/OPG ratio in Saos-2 [90]. There are data matching the activation of osteoblasts by genistein with its binding to oestrogen receptor $\beta$ present on osteoblastic cells [91,92]. Genistein is twenty times more selective for oestrogen receptor $\beta(\mathrm{ER} \beta)$ than $\alpha$ [93]. Animal studies confirmed that genistein combined with silicon and zinc significantly reduced RANKL expression and prevented ovariectomy-induced bone resorption $[94,95]$

Daidzein is the most widely studied soy phytoestrogen. Daidzein was also reported to stimulate osteoblast differentiation. It stimulates osteoblasts through the BMP2/Smad/Runx2 pathway [96]. It was reported that oestrogen receptor signalling, mitogenactivated protein kinase/extracellular signal-regulated kinases (MAPK/ERK), and phosphoinositide-3-kinase/serine-threonine protein kinase B (PI3K/AKT) were involved in osteoblast activation via daidzein [97].

The summary of the influence of isoflavones on bone metabolism is presented in Figure 3.

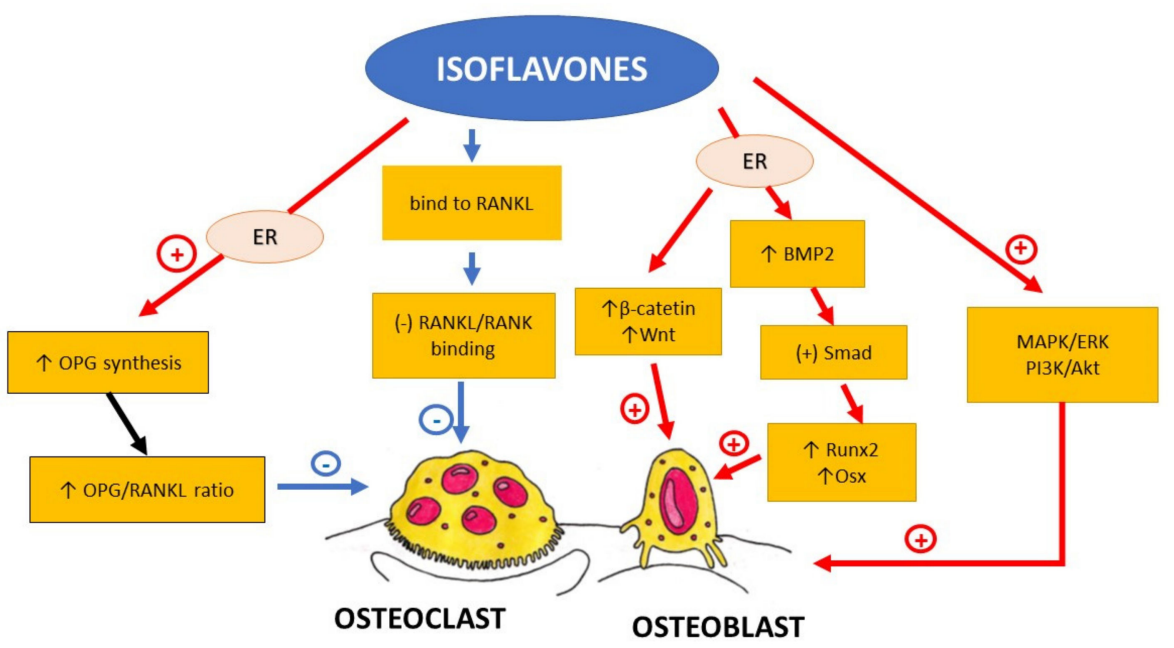

Figure 3. Schematic diagram representing the influence of isoflavones on proliferation, differentiation and activity of osteoclasts and osteoblasts. BMP2-bone morphogenic protein 2, ER-oestrogen receptor, MAPK/ERK—-mitogen-activated protein kinase/extracellular signal-regulated kinases signalling pathway, OPG—osteoprotegerin, Osx-Osteoblast-specific transcription factor Osterix, PI3K/Aktphosphoinositide-3-kinase/serine-threonine kinase signalling pathway, - Receptor Activator for Nuclear Factor kB, RANKL-Receptor Activator for Nuclear Factor кB Ligand, Runx2-Runt-related transcription factor $2, \uparrow$-increased, $\downarrow$-decreased, (-)—inhibited, (+)—activated

\subsubsection{Other Plants Containing Isoflavones}

Alfalfa

Alfalfa (Medicago sativa L.), also called lucerne, belongs, as red clover, to the legume family. It is cultivated as a forage crop in many countries over the world. Its sprouts are a common ingredient of dishes made in Indian cuisine. Alfalfa, as other legumes, is a known source of phytoestrogens, including spinasterol, coumestrol, coumestan, and ipriflavone. As mentioned above, the meta-analysis of 63 controlled trials investigating 6427 postmenopausal women revealed that ipriflavone $(600 \mathrm{mg} /$ day $)$ is a promising molecule for the prevention and treatment of postmenopausal osteoporosis [15]. Ipriflavone has been reported to induce osteoblast proliferation and prevent menopause-related bone loss.

\section{Pueraria candollei var. mirifica}

Pueraria candollei var. mirifica (Airy Shaw and Suvat.) Niyomdham (commonly termed P. mirifica), known also as $k u d z u$ root, has a long history as a postmenopausal rejuvenate therapy for indigenous people. It contains various isoflavones: puerarin, daidzein, daidzin, 
mirficin and salvianololic acid. In a double-blind RCT of healthy postmenopausal women aged 45 to 60 years old, Manonai et al. showed that Pueraria mirifica at a dose of 20,30, and $50 \mathrm{mg} /$ day for a 24-week period demonstrated an oestrogen-like effect on bone turnover. The P1NP level was reduced as seen with other treatments with Er $\alpha$ agonists [50]. In another double-blind RCT, nineteen postmenopausal women (12/7 test/control) received P. mirifica powder or placebo for 2 months. Investigators also found a reduced ALP and commented on its relationship to bone preservation, but the isoform targeted was not stated [51].

Pueraria extract prevented ovariectomy-induced bone loss in rats [98]. Puerarin, that is, the main active ingredient of Pueraria extract, slows down the bone loss and reverses the ovariectomy-induced increase in bone turnover in rats [99]. It also alleviated osteopenia and prevented the deterioration of trabecular structure in $\mathrm{mCT}$ [99]. Other authors reported that puerarin inhibited RANKL-dependent osteoclastogenesis [100], induced mineral nodulus formation in osteoblasts through the activation of PI3K/AKT signalling pathway [101] and promotes osteoblast differentiation [102].

Summing up, isoflavones not only prevent bone resorption by the inhibition of RANKL/RANK interaction and osteoclast maturation and differentiation, but they also seem to promote bone formation. They increase, among others, the expression of BMP2 and Runx2, that are involved in the activation and differentiation of osteoblasts. The molecular mechanism of phytoestrogen influence on bone metabolism is very complex and there are many possible pathways that might be involved (Figure 3).

\subsection{Other Plants Containing Phytoestrogens Investigated in Osteoporosis Treatment}

2.2.1. Epimedium (Berberidaceae)

Epimedium in Clinical Trials

Epimedium is a genus of about 52 species in the family Berberidaceae, which is also known as Rowdy Lamb Herb, Xianlinpi, Barrenwort, Bishop's Hat, Fairy Wings, Horny Goat Weed, and Yangheye or Yin Yang Huo). The traditional Chinese medicinal herb Epimedii has been utilized for centuries to treat bone fractures, bone loss, and menopauseassociated disorders [64]. The results of recent clinical trials have reported suggest that compounds or extracts of Epimedium may prevent or delay the onset of osteoporosis and reduce the risk of hip fractures [21]. Icariin is a prenylated flavonol glycoside isolated from Epimedium herbs, and has been shown to be the main bioactive component [16]. In clinics, Epimedium is used to treat osteoporosis, climacteric period syndrome, breast lumps, hyperpiesia, and coronary heart disease [103].

In a 24-month double-blind RCT in healthy, late postmenopausal women, the intervention group ( $n=50$, a daily dose of $60 \mathrm{mg}$ icariin, $15 \mathrm{mg}$ daidzein, and $3 \mathrm{mg}$ genistein) had a significantly reduced bone loss compared to the placebo group $(n=50)$. Treatment with icariin maintained BMD at 12 months. A long-term (up to 12-24 months) administration of icariin improved BMD in the lumbar spine and femoral neck in a time-dependent manner. Although the effect of icariin is less effective in the improvement in BMD than oestrogen replacement or treatment with bisphosphonates, it seems to be an attractive alternative therapy due to its low risk of severe side effects. It exerted no oestrogenic effect on the uterus and did not change the serum estradiol level, proving its safety when it comes to the endometrium. A 2-year-long treatment with icariin was also not associated with the incidence of breast cancer or cardiovascular events [52]. Further clinical trials encompassing a larger population are needed to investigate the influence of icariin and its derivatives on bone formation and regeneration in humans, as well as its safety profile [16].

\section{Epimedium in Animal Models and In Vitro Studies}

Epimedium flavonoids (icariin, epimedin B, and epimedin C), that possess oestrogenic activity, have been identified as the main constituents of Epimedium plants that exert antiosteoporotic activity, as they inhibit bone resorption, promote bone formation and block urinary calcium excretion [21]. The flavonoids from Epimedium promote osteoblast 
activity through the regulation of the expression of IL-6 (interleukin 6), OPG, RANKL, M-CSF, BMP-2, and Smad4. They modulate the BMP/Smad4 and Wnt/ $\beta$-catenin signalling pathways, inducing osteoblast differentiation [104]. Icariin is the most abundant flavonoid in Herba Epimedii and has a better antiresorptive effect than other components isolated from Epimedium plants. It stimulates bone formation by the promotion of osteoblasts differentiation and the enhancement of their activity $[16,105]$. Icariin activates BMP-2/Smad4, Wnt, and IGF-1 signal transduction pathways [5,17], induces ERK (extracellular signal-regulated kinase), JNK (c-Jun $\mathrm{N}$ terminal kinase) and p38 kinase activation [18]. Icariin not only promotes bone formation, but also inhibits osteoclast differentiation and bone resorption. It decreases RANKL-induced osteoclastogenesis via the modulation of NFKB and MAPK expression and downregulation of main regulators of osteoclastogenesis (c-fos and NFATc1-nuclear factor of activated T-cells, cytoplasmic 1) [19]. Micro-CT results suggest that icariin improves the bone parameters (BMD, bone volume/tissue volume- $\mathrm{BV} / \mathrm{TV}$, connectivity density-Conn.D) and restores bone structure in ovariectomized animals [106]. Ikarisoside A, a flavonoid isolated from Epimedium koreanum, also inhibits RANKL-induced osteoclastogenesis [104].

\subsubsection{Hop (Humulus lupulus L.)}

Hop (Humulus lupulus L.), which belongs to the Cannabaceae family, has been used worldwide in the brewing industry as a source of bitterness in beer. Apart from this, hop extract is known for containing phytoestrogen components and exerting oestrogenic effects. In general, compounds of the oestrogenically active fraction of lupulin gland secretion belong in the following prenylflavonoids: xanthohumol, being the most abundant prenylflavonoid in hops, izoxanthohumol, 6-prenylnaringenin and 8-prenylnaringenin [107]. Moreover, 8-prenylnaringenin has stronger oestrogenic properties than soy phytoestrogens [108]. Ban et al. reported that hop extract Lifenol ${ }^{\circledR}$ prevented osteoporosis development in ovariectomized rats [109]. Hop extract ameliorated the ovariectomy-induced decreased of BMD, femur weight, and BMC (bone mineral content). Additionally, it restored the trabecular structure of calcaneus bone and inhibited ovariectomy-induced osteoclast activation. A mild osteoprotective effect of hop extract was also reported by other authors [110]. Li et al. reported that xanthohumol blocks RANKL-induced osteoblast differentiation and bone resorption, in vitro and in vivo, in ovariectomized mice [111]. At the molecular level, it blocks the RANKL/TRAF6 (tumour necrosis factor receptor associated factor 6) signalling pathway involved in osteoclastogenesis. Additionally, xanthohumol stimulates osteogenic marker gene expression in mesenchymal and pre-osteoblastic cells [112]. Furthermore, 8-prenylnaringenin, that is, the strongest phytoestrogen known, similarly to soy phytoestrogen, exerts its osteoprotective effect through ERs. It inhibits RANKL expression and induces the expression of ostoprotegerin (OPG), which is an inhibitor of osteoclast activity [113].

\section{Other Botanicals}

\subsection{Dried Plums}

\subsubsection{Dried Plums in Clinical Trials}

In a rat model of ovariectomy-induced osteoporosis, dried plum (Prunus domestica L.) prevented the bone loss and structural damage of bone tissue [114]. The studies described below have tried to confirm this effect in humans, mainly in osteopenic postmenopausal women.

Three-month RCT comparing the influence of dried plums versus dried apples on biomarkers of bone formation in 58 postmenopausal women has revealed that the consumption of $100 \mathrm{~g} /$ day dried plums significantly increased the serum markers of bone formation: total ALP, bone-specific ALP (BALP) and IGF-1 [53]. Another one-year RCT compared the effects of daily consumption of $100 \mathrm{~g}$ dried plum to $75 \mathrm{~g}$ dried apple (control) on BMD and biomarkers of bone turnover in 160 osteopenic postmenopausal women. Hooshamnd et al. reported that dried plum improved lumbar and ulnar BMD when compared to dried 
apples [115]. Additionally, the authors reported that dried plum increased RANKL and OPG concentration, and decreased serum sclerostin level, however the reported results did not reach statistical significance [54].

Similarly, inconsistent results were obtained in non-randomized six-month intervention trials evaluating the effects of resistance training with and without dried plum at a dose of $90 \mathrm{~g}$ in 23 postmenopausal breast cancer survivors. In both groups, an improvement of upper and lower body strength was found, but no improvements in body composition or BMD was detected [116]. However, in a subsequent six-month clinical trial evaluating the efficacy of two doses of dried plum $(50 \mathrm{~g}$ vs. $100 \mathrm{~g}$ ) in 48 older postmenopausal women, it was reported that dried plums prevented the loss of total body BMD and reduced the serum concentration of tartrate-resistant acid phosphatase $5 b$ (TRAP-5b). Additionally, the authors concluded that both doses of dried plaums are equally effective [55]. The beneficial effect was also observed in the trial, with 35 men between the ages of 55 and 80 with moderate bone loss. Patients were randomized into one of three groups: $100 \mathrm{~g}$ dried plum daily, $50 \mathrm{~g}$ dried plum daily, or control group. All three groups also consumed a multivitamin containing $450 \mathrm{mg}$ calcium and $800 \mathrm{IU}$ vitamin D. After three months, decreased serum concentration of osteocalcin was observed, as well as an elevation of OPG/RANKL. Authors suggested that regular consumption of either $100 \mathrm{~g}$ or $50 \mathrm{~g}$ dried plum for three months may make some contributions to bone formation and bone turnover activity, and a minimal contribution to decreasing inflammation and improving bone density and quality [56].

The results of the presented studies suggest that dried plum is a promising functional food therapy for preventing bone loss, with the potential for long-lasting bone protective effects [114].

\subsubsection{Dried Plums in Animal Studies and In Vitro Models}

Dried plums contain carbohydrates, vitamins A, B and K, potassium, calcium, magnesium, boron, selenium, dietary fibres, and polyphenols, including chlorogenic acid, rutin and proanthocyanidin [117]. Animal studies comparing the influence of dried plums and standard diet on bone metabolism and bone mechanical properties showed that diet supplementation with dried plums increased vertebral and femoral bone mineral density $[118,119]$. In ovariectomized animals, the administration of dried plums increased bone mineral density and the number of trabeculae (Tb.N.), and decreased the separation of trabeculae (Tb.Sp.) [120,121]. Further animal studies revealed that polyphenols are the main bioactive compounds responsible for bone response to therapy with dried plums. However, the addition of potassium and vitamin $\mathrm{K}$ to the polyphenolic resulted in the additional increase of bone mineral density [122]. In in vitro studies, dried plum polyphenols suppressed osteoclast activity and differentiation [123], increased mineral nodule formation and osteoblast activity [124].

\subsection{Horsetail (Equisetum arvense)}

Horsetail (Equisetum arvense L.) is widely distributed over the northern hemisphere. Extracts and other preparations of horsteil have been used for ages in European folk medicine. It contains abundant constituents that may exert beneficial effects on bone health, e.g., silica, flavonoids, and triterpenoids.

The only clinical study evaluating the effectiveness of horsetail in the treatment of perimenopausal osteoporosis recruited 122 women in menopause for at least two years, who had not undergone oestrogen replacement therapy or drug therapy for recalcification: 30 patients were administered with titrated dry horsetail extract for 80 days; 31 patients were administered with placebo for 40 days and titrated horsetail extract for a further 40 days; 29 patients received no treatment whatsoever; 32 patients were treated with Osteosil Calcium for 80 days. All patients received two tablets per day according to procedures for randomized double-blind studies. Patients who received treatment with titrated horsetail extract after the period of placebo administration showed the same 
changes observed in patients treated with the active ingredient; treatment with titrated horsetail extract and with Osteosil Calcium improved bone metabolism and BMD [57].

E. arvense has a high concentration of silica, and it has been demonstrated in vitro that the horsetail extract induced bone regeneration [125] and inhibited osteoclastogenesis [126]. It has been reported that horsetail extract enhanced bone mineralization and bone formation in ovariectomized rats [127]. Additionally, a diet containing horsetail extract $(120 \mathrm{mg} / \mathrm{kg})$ increased bone mineral density in rats [128]. However, there are scarce studies to support the hypothesis of the beneficial effects of horsetail on bone health, and the European Food Safety Authority concluded that there is not enough evidence of the bone-protecting influence of E. arvense [129].

\subsection{Black Cohosh (Cimcifuga racemosa)}

Data from the following clinical trials suggest the beneficial effects of Cimicifuga racemosa on bone metabolism and bone mineral density. Additionally, the authors hint at the possible reduction of the cumulative dose of HRT for the prophylaxis of osteoporosis in patients receiving CR [130].

A double-blind RCT on postmenopausal women showed that CR stimulated osteoblast activity, and improved markers of bone turnover [58]. Other authors reported that C. racemosa extract reduced bone resorption (decrease in the urinary level of $\mathrm{N}$-telopeptide) and increased bone formation (elevation of ALP) in postmenopausal women. However, serum obtained from treated females did not stimulated osteoblasts' culture, but failed to demonstrate a direct stimulating effect of the serum from treated women on a culture of osteoblasts [59]. On the other hand, other authors did not find a bone-favourable effect of $C$. racemosa extract in exercising early postmenopausal women [60]. The absence of a C. racemosa -taking non-exercising comparison group was a significant shortcoming of this study, as the possibly positive effect of $C$. racemosa might have been lost in the well-known considerable favourable effect of exercise on BMD [131]. Another trial measuring serum osteocalcin and C-terminal telopeptide [132] did not reveal any significant difference between black cohosh and placebo in measured outcome at 12 weeks.

In animal studies, Cimicifuga racemosa increased BMD and restored bone architecture (preventing the decline in BV/TV, Tb.Th., and Tb.N., and preserving SMI-Structural Model Index) in ovariectomized animals [133]. Cycloartane, a tripentoid glycoside isolated from black cohosh, inhibits NFKB and ERK signalling pathways that leads to inhibition of RANKL-induced osteoclast differentiation [134]. Additionally, actein and deoxyactein protect osteoblasts against oxidative stress and promote cell growth and matrix mineralisation $[135,136]$.

\subsection{Salvia miltiorrhiza and Salvia plebia}

Red sage (Salvia miltiorrhiza Bunge), also known as Danshen in Chinese, has been used to treat bone diseases in traditional Chinese medicine. Guo et al. analyzed clinical trials that investigated the efficacy of Salvia miltiorrhiza in the treatment of osteoporosis. In reported trials S. miltiorrhiza was given as monotherapy or as a part of combined therapy with other plants or ingredients. They identified 36 trials that demonstrated high efficacy and no toxicity of $S$. miltiorrhiza, however, in some studies, small patient samples, short treatment duration, frequent lack of detailed numerical data, and no clear endpoints limited their value and reliability [137]. S. miltiorrhiza influence on bone regeneration was also investigated in patients with avascular and ischemic necrosis of femoral head. S. miltiorrhiza was injected and implantated in the calcium phosphate cement/S. miltiorrhiza drug delivery system by minimal invasive surgery. The digital substruction arterography and X-ray films demonstrated that $S$. miltiorrhiza administration improved the microcirculation and regeneration of the affected bone [138].

In animal studies, S. miltiorrhiza and S. plebia prevented ovariectomy-induced decrease in trabecular bone mass and BMD. It also reduced TRAP5b activity and oxidative stress in ovariectomised animals $[22,26,139]$. Tashinones, salvianolic acid, and eudebeiolide B 
have been identified as osteoprotective components of Salivia plants. Tanshinones inhibit the formation of TRAP5b-expressing osteoclasts by suppressing the RANKL-induced expression of c-fos and NFATc1 [22,23]. Salvianolic acid A and B modulate osteoblast differentiation and upregulate osteoblast activity $[24,25]$. Liu et al. reported that Radix salviae improves bone microarchitecture and biomechanical properties through the Wnt/ $\beta$ catening signalling pathway in ovariectomized rats [140].

\subsection{Other Herbs}

\subsubsection{Labisia pumila and Eurycoma longifolia}

Labisia pumila that belongs to the family Myrsinaceae is used in Asia for the treatment of painful menstruation and disorders of sexual life in females due to its oestrogenic properties. As a phytoestrogen-containing plant, it is also used in osteoporosis treatment [141].

Both L. pumila and E. longifolia have demonstrated a protective effect on bone loss due to osteoporosis in previously published studies. In a double-blind, 24-week RCT, 119 healthy women (aged 41-55 years) experiencing peri-menopausal or menopausal symptoms were enrolled and supplemented with herbal formulation $\left(\mathrm{Nu}-\mathrm{femme}^{\mathrm{TM}}\right) \mathrm{com}-$ prising LP $\left(\mathrm{SLP}+{ }^{\circledR}\right)$ and Eurycoma longifolia $\left(\right.$ Physta $\left.{ }^{\circledR}\right)$ or placebo. There were no significant differences between- and within-group of bone markers for osteoporosis reflecting bone formation (BALP) and resorption (N-terminal telopeptide-NTX) [61].

\subsubsection{Drynaria fortunei}

Rhizoma Drynariae, the dried rhizome of Drynaria fortunei (Kunze) J. Sm., is reported to prevent age-associated bone loss. It contains mainly flavonoids, triterpenoids, phenolic acids, and glycosides [142]. In ovariectomized animals, Rhizoma Drynariae extract prevented oestrogen deficiency-induced weight gain without an unfavourable effect on the uterus [143]. Additionally, it exerted a protective effect on bone, increasing Tb.N. and bone fraction (BV/TV), and decreased Tb.Sp. in calcaneus bone. In vitro studies revealed that Rhizoma Drynariae extract inhibits RANK activity [143]. Sun et al. reported that polysaccharides from Rhizoma Drynariae exerts an antiosteoporotic effect in ovariectomized rats. It maintained trabecular microarchitecture and bone biomechanical properties, and increased femoral and tibial bone mineral density (BMD) [144].

\subsubsection{Other Plant-Derived Constituents}

As there is a great need to develop new drugs that might be used in the treatment of osteoporosis, there are plenty of reports on studies investigating the influence of plantderived bioactive substances on the activity and differentiation of osteoclasts and osteoblasts. Loureirin B (flavonoid, extracted from Dracaena cochinchinensis) and kirenol (diterpenoid extracted from the Chinese herbal medicine Siegesbeckiae) inhibit RANKLinduced osteoclast differentiation by attenuation of NFAT expression $[145,146]$. Kaempferol (natural flavonol found in various plants, e.g., tea and broccoli) that exerts oestrogenic properties, on the one hand, inhibits bone resorption and on the other promotes bone formation [147]. Its bone-protective effect is mediated through regulation of oestrogen receptor, bone morphogenetic protein-2 (BMP-2), NF- $\mathrm{kB}$, MAPK and mammalian target of rapamycin (mTOR) signalling pathways [148]. Mangiferin (xanthone originally extracted from mango tree) attenuates ovariectomy-induced osteoporosis in rats [149] and promotes osteoblast differentiation through the increased expression of Runx2 and BMP2/Smad1 signalling pathway $[150,151]$. Quercetin (flavanol wildly distributed in plants, e.g., red onion) inhibits RANKL-mediated osteoblastogenesis through Wnt, NFKB, Nrf2 (nuclear factor erythroid 2-related factor 2), and SMAD-dependent signalling pathways [152].

\section{Conclusions}

Traditional folk medicine is a rich source of bioactive compounds waiting for discovery and investigation that might be used in treatment and prophylaxis od osteoporosis. The mechanism of action of some chosen botanicals are presented in Figure 4 and Table 2. 


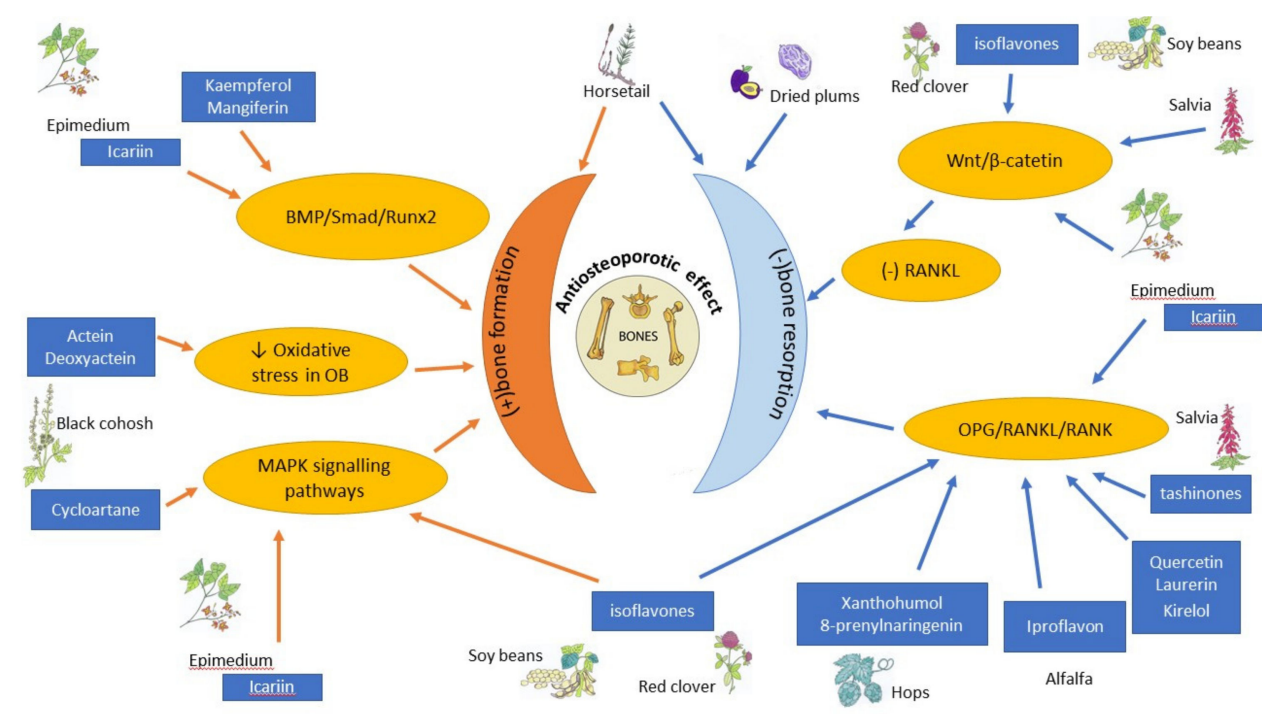

Figure 4. Schematic diagram of the antiosteoporotic activity of various plants and their components. BMP-bone morphogenic protein, MAPK—-mitogen-activated protein kinase, OB — osteoblast, OPG—osteoprotegerin, RANK—Receptor Activator for Nuclear Factor kB, RANKL—Receptor Activator for Nuclear Factor $\kappa B$ Ligand, Runx2-Runt-related transcription factor $2, \downarrow$ decreased, (-)—inhibited, (+) activated

Author Contributions: Conceptualization, W.S. and B.N.; methodology, B.N.; resources, W.S. and B.N.; original draft preparation, W.S., P.J. and B.N.; writing-review and editing, B.N.; visualization, P.J. All authors have read and agreed to the published version of the manuscript.

Funding: This research received no external funding.

Institutional Review Board Statement: Not applicable.

Informed Consent Statement: Not applicable.

Data Availability Statement: No new data were created or analyzed in this study. Data sharing is not applicable to this article.

Conflicts of Interest: The authors declare no conflict of interest.

$\begin{array}{ll}\text { Abbreviations } \\ \text { AKT } & \text { protein kinase B } \\ \text { ALP } & \text { alkaline phosphatase } \\ \text { BALP } & \text { bone-specific alkaline phosphatase } \\ \text { bFGF } & \text { basic fibroblast growth factor } \\ \text { BMC } & \text { bone mineral content (BMC) } \\ \text { BMD } & \text { bone mineral density } \\ \text { BMP } & \text { bone morphogenic protein } \\ \text { BMSC } & \text { bone marrow-derived mesenchymal stem cells } \\ \text { BV/TV } & \text { bone fraction } \\ \text { c-FMS } & \text { colony-stimulating factor-1 receptor } \\ \text { Conn.D. } & \text { connectivity density } \\ \text { CTX } & \text { type I collagen crosslinked beta C-telopeptide } \\ \text { DPD } & \text { deoxypyridinoline } \\ \text { ER } & \text { oestrogen receptor } \\ \text { ERK } & \text { extracellular signal-regulated kinases } \\ \text { FasL } & \text { Fas ligand }\end{array}$




\begin{tabular}{|c|c|}
\hline bFGF & basic fibroblast growth factor \\
\hline $\mathrm{Hh}$ & Hedgehog \\
\hline HRT & hormonal replacement therapy \\
\hline IGF & insulin-like growth factor \\
\hline IL-6 & interleukin 6 \\
\hline JNK & c-Jun $\mathrm{N}$ terminal kinase \\
\hline MAPK & mitogen-activated protein kinase \\
\hline M-CSF & macrophage colony-stimulating factor \\
\hline $\mathrm{mCT}$ & micro-computed tomography \\
\hline mRNA & messenger ribonucleic acid \\
\hline mTOR & mechanistic target of rapamycin \\
\hline NFAT-c1 & Nuclear factor of activated T-cells, cytoplasmic 1 \\
\hline NFkB & nuclear factor-kappa B \\
\hline Nrf2 & nuclear factor erythroid 2-related factor 2 \\
\hline NTX & type I collagen crosslinked N- telopeptide \\
\hline OB & osteoblast \\
\hline OC & osteoclast \\
\hline OPG & osteoprotegerin \\
\hline OSX & Osterix \\
\hline P1NP & type I procollagen-N-propeptide \\
\hline PDGF & platelet-derived growth factor \\
\hline PI3K/AKT & phosphoinositide-3-kinase/serine-threonine protein kinase B \\
\hline PLC & phospholipase C \\
\hline pre-OB & pre-osteoblasts \\
\hline pre-OC & pre-osteoclasts \\
\hline PTH & parathyroid hormone \\
\hline RANK & Receptor Activator for Nuclear Factor $\mathrm{kB}$ \\
\hline RANKL & Receptor Activator for Nuclear Factor кB Ligand \\
\hline $\mathrm{RCT}$ & randomized clinical trial \\
\hline Runx2 & Runt-related transcription factor 2 \\
\hline SERM & Selective Oestrogen Receptor Modulator \\
\hline sFasL & soluble Fas lignad \\
\hline SMI & Structural Model Inde \\
\hline Tb.N. & number of trabeculae \\
\hline Tb.Sp. & separation of trabeculae \\
\hline Tb.Th. & trabecular thickness \\
\hline TGF $\beta$ & tumour growth factor $\beta$ \\
\hline TRAF6 & tumour necrosis factor receptor associated factor 6 \\
\hline TRAP 5b & Tartrate-resistant acid phosphatase $5 \mathrm{~b}$ \\
\hline
\end{tabular}

\section{References}

1. Consensus development conference: Diagnosis, prophylaxis, and treatment of osteoporosis. Am. J. Med. 1993, 94, 646-650. [CrossRef]

2. Bartl, R.; Bartl, C. Epidemiology of osteoporotic fractures. In The Osteoporosis Manual; Springer International Publishing: Cham, Switzerland, 2019; pp. 231-232.

3. Hernlund, E.; Svedbom, A.; Ivergård, M.; Compston, J.E.; Cooper, C.; Stenmark, J.; McCloskey, E.V.; Jonsson, B.; Kanis, J.A. Osteoporosis in the European Union: Medical management, epidemiology and economic burden. Arch. Osteoporos. 2013, 8, 136. [CrossRef] [PubMed]

4. Kanis, J.; Cooper, C.; Rizzoli, R.; Reginster, J.Y.; On behalf of the Scientific Advisory Board of the European Society for Clinical and Economic Aspects of Osteoporosis (ESCEO) and the Committees of Scientific Advisors and National Societies of the International Osteoporosis Foundation (IOF); Cooper, C.; Rizzoli, R.; Reginster, J.-Y. European guidance for the diagnosis and management of osteoporosis in Postmenopausal women. Osteoporos. Int. 2019, 30, 3-44. [CrossRef]

5. Bellavia, D.; Dimarco, E.; Costa, V.; Carina, V.; De Luca, A.; Raimondi, L.; Fini, M.; Gentile, C.; Caradonna, F.; Giavaresi, G. Flavonoids in Bone Erosive Diseases: Perspectives in Osteoporosis Treatment. Trends Endocrinol. Metab. 2021, 32, 76-94. [CrossRef]

6. Cauley, J.A. Estrogen and bone health in men and women. Steroids 2015, 99, 11-15. [CrossRef]

7. Khalid, A.B.; Krum, S.A. Estrogen receptors alpha and beta in bone. Bone 2016, 87, 130-135. [CrossRef]

8. Krum, S.A.; Chang, J.; Miranda-Carboni, G.; Wang, C.-Y. Novel functions for NFkB: Inhibition of bone formation. Nat. Rev. Rheumatol. 2010, 6, 607-611. [CrossRef] [PubMed] 
9. Garcia, A.J.; Tom, C.; Guemes, M.; Polanco, G.; Mayorga, M.E.; Wend, K.; Miranda-Carboni, G.A.; Krum, S.A. ER $\alpha$ signaling regulates MMP3 expression to induce FasL cleavage and osteoclast apoptosis. J. Bone Miner. Res. 2013, 28, 283-290. [CrossRef]

10. Martin, A.; Xiong, J.; Koromila, T.; Ji, J.S.; Chang, S.; Song, Y.S.; Miller, J.L.; Han, C.-Y.; Kostenuik, P.; Krum, S.A.; et al. Estrogens antagonize RUNX2-mediated osteoblast-driven osteoclastogenesis through regulating RANKL membrane association. Bone 2015, 75, 96-104. [CrossRef]

11. Gazzerro, E.; Canalis, E. Bone morphogenetic proteins and their antagonists. Rev. Endocr. Metab. Disord. 2006, 7, 51-65. [CrossRef]

12. Canalis, E. Wnt signalling in osteoporosis: Mechanisms and novel therapeutic approaches. Nat. Rev. Endocrinol. 2013, 9, 575-583. [CrossRef] [PubMed]

13. Canalis, E. Skeletal Growth Factors. In Osteoporosis; Elsevier Academic Press: Cambridge, MA, USA, 2013 ; pp. $391-410$.

14. Gómez-Zorita, S.; González-Arceo, M.; Fernández-Quintela, A.; Eseberri, I.; Trepiana, J.; Portillo, M.P. Scientific Evidence Supporting the Beneficial Effects of Isoflavones on Human Health. Nutrients 2020, 12, 3853. [CrossRef]

15. Sansai, K.; Na Takuathung, M.; Khatsri, R.; Teekachunhatean, S.; Hanprasertpong, N.; Koonrungsesomboon, N. Effects of isoflavone interventions on bone mineral density in postmenopausal women: A systematic review and meta-analysis of randomized controlled trials. Osteoporos. Int. 2020, 31, 1853-1864. [CrossRef]

16. Wang, Z.; Wang, D.; Yang, D.; Zhen, W.; Zhang, J.; Peng, S. The effect of icariin on bone metabolism and its potential clinical application. Osteoporos. Int. 2018, 29, 535-544. [CrossRef] [PubMed]

17. Liang, W.; Lin, M.; Li, X.; Li, C.; Gao, B.; Gan, H.; Yang, Z.; Lin, X.; Liao, L.; Yang, M. Icariin promotes bone formation via the BMP-2/Smad4 signal transduction pathway in the hFOB 1.19 human osteoblastic cell line. Int. J. Mol. Med. 2012, 30, 889-895. [CrossRef] [PubMed]

18. Song, L.; Zhao, J.; Zhang, X.; Li, H.; Zhou, Y. Icariin induces osteoblast proliferation, differentiation and mineralization through estrogen receptor-mediated ERK and JNK signal activation. Eur. J. Pharmacol. 2013, 714, 15-22. [CrossRef]

19. Xu, Q.; Chen, G.; Liu, X.; Dai, M.; Zhang, B. Icariin inhibits RANKL-induced osteoclastogenesis via modulation of the NF- $k B$ and MAPK signaling pathways. Biochem. Biophys. Res. Commun. 2019, 508, 902-906. [CrossRef]

20. Ming, L.-G.; Lv, X.; Ma, X.-N.; Ge, B.-F.; Zhen, P.; Song, P.; Zhou, J.; Ma, H.-P.; Xian, C.J.; Chen, K.-M. The Prenyl Group Contributes to Activities of Phytoestrogen 8-Prenynaringenin in Enhancing Bone Formation and Inhibiting Bone Resorption In Vitro. Endocrinology 2013, 154, 1202-1214. [CrossRef]

21. Indran, I.R.; Liang, R.L.Z.; Min, T.E.; Yong, E.-L. Preclinical studies and clinical evaluation of compounds from the genus Epimedium for osteoporosis and bone health. Pharmacol. Ther. 2016, 162, 188-205. [CrossRef]

22. Kim, H.-K.; Woo, E.-R.; Lee, H.-W.; Park, H.-R.; Kim, H.-N.; Jung, Y.-K.; Choi, J.-Y.; Chae, S.-W.; Kim, H.-R.; Chae, H.-J. The Correlation of Salvia miltiorrhiza Extract-Induced Regulation of Osteoclastogenesis with the Amount of Components Tanshinone I, Tanshinone IIA, Cryptotanshinone, and Dihydrotanshinone. Immunopharmacol. Immunotoxicol. 2008, 30, 347-364. [CrossRef]

23. Cheng, L.; Zhou, S.; Zhao, Y.; Sun, Y.; Xu, Z.; Yuan, B.; Chen, X. Tanshinone IIA attenuates osteoclastogenesis in ovariecto-mized mice by inactivating NF-kB and Akt signaling pathways. Am. J. Transl. Res. 2018, 10, 1457-1468.

24. Cui, L.; Liu, Y.-Y.; Wu, T.; Ai, C.-M.; Chen, H.-Q. Osteogenic effects of D(+)ß-3,4-dihydroxyphenyl lactic acid (salvianic acid A, SAA) on osteoblasts and bone marrow stromal cells of intact and prednisone-treated rats. Acta Pharmacol. Sin. 2009, 30, 321-332. [CrossRef] [PubMed]

25. Cui, L.; Li, T.; Liu, Y.; Zhou, L.; Li, P.; Xu, B.; Huang, L.; Chen, Y.; Liu, Y.; Tian, X.; et al. Salvianolic Acid B Prevents Bone Loss in Prednisone-Treated Rats through Stimulation of Osteogenesis and Bone Marrow Angiogenesis. PLoS ONE 2012, 7, e34647. [CrossRef]

26. Kim, M.-H.; Lim, H.-J.; Bak, S.G.; Park, E.-J.; Jang, H.-J.; Lee, S.; Lee, S.; Lee, K.M.; Cheong, S.H.; Lee, S.-J.; et al. Eudebeiolide B Inhibits Osteoclastogenesis and Prevents Ovariectomy-Induced Bone Loss by Regulating RANKL-Induced NF- $\mathrm{B}$, c-Fos and Calcium Signaling. Pharmaceuticals 2020, 13, 468. [CrossRef]

27. Scheiber, M.D.; Liu, J.H.; Subbiah, M.T.R.; Rebar, R.W.; Setchell, K.D.R. Dietary inclusion of whole soy foods results in significant reductions in clinical risk factors for osteoporosis and cardiovascular disease in normal postmenopausal women. Menopause 2001, 8, 384-392. [CrossRef]

28. Chiechi, L.M.; Secreto, G.; D’Amore, M.; Fanelli, M.; Venturelli, E.; Cantatore, F.; Valerio, T.; LaSelva, G.; Loizzi, P. Efficacy of a soy rich diet in preventing postmenopausal osteoporosis: The Menfis randomized trial. Maturitas 2002, 42, 295-300. [CrossRef]

29. Chen, Y.-M.; Ho, S.C.; Lam, S.S.H.; Ho, S.S.S.; Woo, J.L.F. Beneficial effect of soy isoflavones on bone mineral content was modified by years since menopause, body weight, and calcium intake: A double-blind, randomized, controlled trial. Menopause 2004, 11, 246-254. [CrossRef]

30. Ye, Y.-B.; Tang, X.-Y.; Verbruggen, M.A.; Su, Y.-X. Soy isoflavones attenuate bone loss in early postmenopausal Chinese women. Eur. J. Nutr. 2006, 45, 327-334. [CrossRef]

31. Wu, J.; Oka, J.; Ezaki, J.; Ohtomo, T.; Ueno, T.; Uchiyama, S.; Toda, T.; Uehara, M.; Ishimi, Y. Possible role of equol status in the effects of isoflavone on bone and fat mass in postmenopausal Japanese women. Menopause 2007, 14, 866-874. [CrossRef]

32. Shedd-Wise, K.M.; Alekel, D.L.; Hofmann, H.; Hanson, K.B.; Schiferl, D.J.; Hanson, L.N.; Van Loan, M.D. The Soy Isoflavones for Reducing Bone Loss Study: 3-Yr Effects on pQCT Bone Mineral Density and Strength Measures in Postmenopausal Women. J. Clin. Densitom. 2011, 14, 47-57. [CrossRef]

33. Lee, H.; Choue, R.; Lim, H. Effect of soy isoflavones supplement on climacteric symptoms, bone biomarkers, and quality of life in Korean postmenopausal women: A randomized clinical trial. Nutr. Res. Pract. 2017, 11, 223-231. [CrossRef] [PubMed] 
34. Tit, D.M.; Bungau, S.; Iovan, C.; Cseppento, D.C.N.; Endres, L.; Sava, C.; Sabau, A.M.; Furau, G.; Furau, C. Effects of the Hormone Replacement Therapy and of Soy Isoflavones on Bone Resorption in Postmenopause. J. Clin. Med. 2018, 7, 297. [CrossRef]

35. Sathyapalan, T.; Aye, M.; Rigby, A.S.; Fraser, W.D.; Thatcher, N.J.; Kilpatrick, E.S.; Atkin, S.L. Soy Reduces Bone Turnover Markers in Women During Early Menopause: A Randomized Controlled Trial. J. Bone Miner. Res. 2016, 32, 157-164. [CrossRef] [PubMed]

36. Levis, S.; Strickman-Stein, N.; Ganjei-Azar, P.; Xu, P.; Doerge, D.R.; Krischer, J. Soy Isoflavones in the Prevention of Menopausal Bone Loss and Menopausal Symptoms. Arch. Intern. Med. 2011, 171, 1363-1369. [CrossRef]

37. Kreijkamp-Kaspers, S.; Kok, L.; Grobbee, D.E.; De Haan, E.H.F.; Aleman, A.; Lampe, J.W.; Van Der Schouw, Y.T. Effect of Soy Protein Containing Isoflavones on Cognitive Function, Bone Mineral Density, and Plasma Lipids in Postmenopausal Women. JAMA 2004, 292, 65-74. [CrossRef] [PubMed]

38. Brink, E.; Coxam, V.; Robins, S.; Wahala, K.; Cassidy, A.; Branca, F.; PHYTOS Investigators. Long-term consumption of isoflavoneenriched foods does not affect bone mineral density, bone metabolism, or hormonal status in early postmenopausal women: A randomized, double-blind, placebo controlled study. Am. J. Clin. Nutr. 2008, 87, 761-770. [CrossRef]

39. Marini, H.; Minutoli, L.; Polito, F.; Bitto, A.; Altavilla, D.; Atteritano, M.; Gaudio, A.; Mazzaferro, S.; Frisina, A.; Frisina, N.; et al. Effects of the Phytoestrogen Genistein on Bone Metabolism in Osteopenic Postmenopausal Women. Ann. Intern. Med. 2007, 146, 839-847. [CrossRef] [PubMed]

40. Marini, H.R.; Bitto, A.; Altavilla, D.; Burnett, B.P.; Polito, F.; Di Stefano, V.; Minutoli, L.; Atteritano, M.; Levy, R.M.; D’Anna, R.; et al. Breast Safety and Efficacy of Genistein Aglycone for Postmenopausal Bone Loss: A Follow-Up Study. J. Clin. Endocrinol. Metab. 2008, 93, 4787-4796. [CrossRef]

41. Atteritano, M.; Mazzaferro, S.; Frisina, A.; Cannata, M.L.; Bitto, A.; D’Anna, R.; Squadrito, F.; Macrì, I.; Frisina, N.; Buemi, $\mathrm{M}$. Genistein effects on quantitative ultrasound parameters and bone mineral density in osteopenic postmenopausal women. Osteoporos. Int. 2009, 20, 1947-1954. [CrossRef]

42. Lappe, J.; Kunz, I.; Bendik, I.; Prudence, K.; Weber, P.; Recker, R.; Heaney, R.P. Effect of a combination of genistein, polyunsaturated fatty acids and vitamins D3 and K1 on bone mineral density in postmenopausal women: A randomized, placebo-controlled, double-blind pilot study. Eur. J. Nutr. 2013, 52, 203-215. [CrossRef]

43. Arcoraci, V.; Atteritano, M.; Squadrito, F.; D’Anna, R.; Marini, H.R.; Santoro, D.; Minutoli, L.; Messina, S.; Altavilla, D.; Bitto, A. Antiosteoporotic Activity of Genistein Aglycone in Postmenopausal Women: Evidence from a Post-Hoc Analysis of a Multicenter Randomized Controlled Trial. Nutrients 2017, 9, 179. [CrossRef]

44. Clifton-Bligh, P.B.; Baber, R.J.; Fulcher, G.R.; Nery, M.-L.; Moreton, T. The effect of isoflavones extracted from red clover (Rimostil) on lipid and bone metabolism. Menopause 2001, 8, 259-265. [CrossRef] [PubMed]

45. Atkinson, C.; Compston, J.E.; Day, N.E.; Dowsett, M.; Bingham, S.A. The effects of phytoestrogen isoflavones on bone density in women: A double-blind, randomized, placebo-controlled trial. Am. J. Clin. Nutr. 2004, 79, 326-333. [CrossRef] [PubMed]

46. Lambert, M.N.T.; Thybo, C.B.; Lykkeboe, S.; Rasmussen, L.M.; Frette, X.; Christensen, L.P.; Jeppesen, P.B. Combined bioavailable isoflavones and probiotics improve bone status and estrogen metabolism in postmenopausal osteopenic women: A randomized controlled trial. Am. J. Clin. Nutr. 2017, 106, ajcn153353-920. [CrossRef]

47. Thorup, A.C.; Lambert, M.N.; Kahr, H.S.; Bjerre, M.; Jeppesen, P.B. Intake of Novel Red Clover Supplementation for 12 Weeks Improves Bone Status in Healthy Menopausal Women. Evid.-Based Complement. Altern. Med. 2015, 2015, 9138. [CrossRef]

48. Powles, T.J.; Howell, A.; Evans, D.G.; McCloskey, E.V.; Ashley, S.; Greenhalgh, R.; Affen, J.; Flook, L.A.; Tidy, A. Red clover isoflavones are safe and well tolerated in women with a family history of breast cancer. Menopause Int. Integr. J. Postreproductive Health 2008, 14, 6-12. [CrossRef]

49. Schult, T.M.K.; Ensrud, K.E.; Blackwell, T.; Ettinger, B.; Wallace, R.; Tice, J.A. Effect of isoflavones on lipids and bone turnover markers in menopausal women. Maturitas 2004, 48, 209-218. [CrossRef] [PubMed]

50. Manonai, J.; Chittacharoen, A.; Udomsubpayakul, U.; Theppisai, H.; Theppisai, U. Effects and safety of Pueraria mirifica on lipid profiles and biochemical markers of bone turnover rates in healthy postmenopausal women. Menopause 2008, 15, 530-535. [CrossRef]

51. Okamura, S.; Sawada, Y.; Satoh, T.; Sakamoto, H.; Saito, Y.; Sumino, H.; Takizawa, T.; Kogure, T.; Chaichantipyuth, C.; Higuchi, Y.; et al. Pueraria Mirifica Phytoestrogens Improve Dyslipidemia in Postmenopausal Women Probably by Activating Estrogen Receptor Subtypes. Tohoku J. Exp. Med. 2008, 216, 341-351. [CrossRef]

52. Zhang, G.; Qin, L.; Shi, Y. Epimedium-Derived Phytoestrogen Flavonoids Exert Beneficial Effect on Preventing Bone Loss in Late Postmenopausal Women: A 24-Month Randomized, Double-Blind and Placebo-Controlled Trial. J. Bone Miner. Res. 2007, 22, 1072-1079. [CrossRef]

53. Arjmandi, B.H.; Khalil, D.A.; Lucas, E.A.; Georgis, A.; Stoecker, B.J.; Hardin, C.; Payton, M.E.; Wild, R.A. Dried Plums Improve Indices of Bone Formation in Postmenopausal Women. J. Women's Heal. Gender-Based Med. 2002, 11, 61-68. [CrossRef]

54. Hooshmand, S.; Brisco, J.R.Y.; Arjmandi, B.H. The effect of dried plum on serum levels of receptor activator of NF- $k B$ ligand, osteoprotegerin and sclerostin in osteopenic postmenopausal women: A randomised controlled trial. Br. J. Nutr. 2014, 112, 55-60. [CrossRef] [PubMed]

55. Hooshmand, S.; Kern, M.; Metti, D.; Shamloufard, P.; Chai, S.C.; Johnson, S.A.; Payton, M.E.; Arjmandi, B.H. The effect of two doses of dried plum on bone density and bone biomarkers in osteopenic postmenopausal women: A randomized, controlled trial. Osteoporos. Int. 2016, 27, 2271-2279. [CrossRef] 
56. Arjmandi, B.; George, K.; Ormsbee, L.; Akhavan, N.; Munoz, J.; Foley, E.; Siebert, S. The Short-Term Effects of Prunes in Preventing Inflammation and Improving Indices of Bone Health in Osteopenic Men. Curr. Dev. Nutr. 2020, 4, 5. [CrossRef]

57. Corletto, F. Female climacteric osteoporosis therapy with titrated horsetail (Equisetum arvense) extract plus calcium (osteosil calcium): Randomized double blind study. Minerva Ortop. Traumatol. 1999, 50, 201-206.

58. Wuttke, W.; Gorkow, C.; Seidlová-Wuttke, D. Effects of black cohosh (Cimicifuga racemosa) on bone turnover, vaginal mucosa, and various blood parameters in postmenopausal women. Menopause 2006, 13, 185-196. [CrossRef] [PubMed]

59. García-Pérez, M.A.; Pineda, B.; Hermenegildo, C.; Tarín, J.J.; Cano, A. Isopropanolic Cimicifuga racemosa is favorable on bone markers but neutral on an osteoblastic cell line. Fertil. Steril. 2009, 91, 1347-1350. [CrossRef] [PubMed]

60. Bebenek, M.; Kemmler, W.; von Stengel, S.; Engelke, K.; Kalender, W.A. Effect of exercise and Cimicifuga racemosa (CR BNO 1055) on bone mineral density, 10-year coronary heart disease risk, and menopausal complaints. Menopause 2010, 17, 791-800. [CrossRef] [PubMed]

61. Chinnappan, S.M.; George, A.; Evans, M.; Anthony, J. Efficacy of Labisia pumila and Eurycoma longifolia standardised extracts on hot flushes, quality of life, hormone and lipid profile of peri-menopausal and menopausal women: A randomised, placebo-controlled study. Food Nutr. Res. 2020, 64, 1-15. [CrossRef]

62. Křǐžová, L.; Dadáková, K.; Kašparovská, J.; Kašparovský, T. Isoflavones. Molecules 2019, 24, 1076. [CrossRef]

63. Cassidy, A.; Peñalvo, J.; Hollman, P. Bioavailability of isoflavones in humans. In Flavonoids and Related Compounds: Bioavail-ability and Function; CRC Press: Boca Raton, FL, USA, 2012; ISBN 9781439848272.

64. Jolly, J.J.; Chin, K.-Y.; Alias, E.; Chua, K.H.; Soelaiman, I.N. Protective Effects of Selected Botanical Agents on Bone. Int. J. Environ. Res. Public Health 2018, 15, 963. [CrossRef]

65. Collison, M.W. Determination of Total Soy Isoflavones in Dietary Supplements, Supplement Ingredients, and Soy Foods by High-Performance Liquid Chromatography with Ultraviolet Detection: Collaborative Study. J. AOAC Int. 2008, 91, 489-500. [CrossRef] [PubMed]

66. Zhang, X.; Shu, X.-O.; Li, H.; Yang, G.; Li, Q.; Gao, Y.-T.; Zheng, W. Prospective Cohort Study of Soy Food Consumption and Risk of Bone Fracture Among Postmenopausal Women. Arch. Intern. Med. 2005, 165, 1890-1895. [CrossRef] [PubMed]

67. Dennison, E.; Yoshimura, N.; Hashimoto, T.; Cooper, C. Bone loss in Great Britain and Japan: A comparative longitudinal study. Bone 1998, 23, 379-382. [CrossRef] [PubMed]

68. Ross, P.D.; Norimatsu, H.; Davis, J.W.; Yano, K.; Wasnich, R.D.; Fujiwara, S.; Hosoda, Y.; Melton, I.L.J. A Comparison of Hip Fracture Incidence among Native Japanese, Japanese Americans, and American Caucasians. Am. J. Epidemiol. 1991, 133, 801-809. [CrossRef] [PubMed]

69. Atteritano, M.; Pernice, F.; Mazzaferro, S.; Mantuano, S.; Frisina, A.; D'Anna, R.; Cannata, M.L.; Bitto, A.; Squadrito, F.; Frisina, N.; et al. Effects of phytoestrogen genistein on cytogenetic biomarkers in postmenopausal women: 1 year randomized, placebo-controlled study. Eur. J. Pharmacol. 2008, 589, 22-26. [CrossRef]

70. Pawlowski, J.W.; Martin, B.R.; McCabe, G.P.; McCabe, L.D.; Jackson, G.S.; Peacock, M.; Barnes, S.; Weaver, C.M. Impact of equol-producing capacity and soy-isoflavone profiles of supplements on bone calcium retention in postmenopausal women: A randomized crossover trial. Am. J. Clin. Nutr. 2015, 102, 695-703. [CrossRef]

71. Lambert, M.N.T.; Hu, L.M.; Jeppesen, P.B. A systematic review and meta-analysis of the effects of isoflavone formulations against estrogen-deficient bone resorption in peri- and postmenopausal women. Am. J. Clin. Nutr. 2017, 106, ajcn151464-811. [CrossRef]

72. Akhlaghi, M.; Nasab, M.G.; Riasatian, M.; Sadeghi, F. Soy isoflavones prevent bone resorption and loss, a systematic review and meta-analysis of randomized controlled trials. Crit. Rev. Food Sci. Nutr. 2019, 60, 2327-2341. [CrossRef]

73. Abdi, F.; Alimoradi, Z.; Haqi, P.; Mahdizad, F. Effects of phytoestrogens on bone mineral density during the menopause transition: A systematic review of randomized, controlled trials. Climacteric 2016, 19, 535-545. [CrossRef]

74. Liu, J.; Ho, S.C.; Su, Y.-X.; Chen, W.-Q.; Zhang, C.-X.; Chen, Y.-M. Effect of long-term intervention of soy isoflavones on bone mineral density in women: A meta-analysis of randomized controlled trials. Bone 2009, 44, 948-953. [CrossRef] [PubMed]

75. Jin, Y.-X.; Wu, P.; Mao, Y.-F.; Wang, B.; Zhang, J.-F.; Chen, W.-L.; Liu, Z.; Shi, X.-L. Chinese Herbal Medicine for Osteoporosis: A Meta-analysis of Randomized Controlled Trials. J. Clin. Densitom. 2017, 20, 516-525. [CrossRef]

76. Zhai, Y.; Li, Y.; Wang, Y.; Cui, J.; Feng, K.; Kong, X.; Chen, L. Psoralidin, a prenylated coumestan, as a novel anti-osteoporosis candidate to enhance bone formation of osteoblasts and decrease bone resorption of osteoclasts. Eur. J. Pharmacol. 2017, 801, 62-71. [CrossRef]

77. Chopra, B.; Dhingra, A.K.; Dhar, K.L. Psoralea corylifolia L. (Buguchi)—Folklore to modern evidence: Review. Fitoterapia 2013, 90, 44-56. [CrossRef]

78. Nieves, J.W. Skeletal effects of nutrients and nutraceuticals, beyond calcium and vitamin D. Osteoporos. Int. 2013, 24, 771-786. [CrossRef]

79. Kim, M.R.; Kim, H.J.; Yu, S.H.; Lee, B.S.; Jeon, S.Y.; Lee, J.J.; Lee, Y.C. Combination of Red Clover and Hops Extract Improved Menopause Symptoms in an Ovariectomized Rat Model. Evid.-Based Complement. Altern. Med. 2020, 2020, 1391. [CrossRef]

80. Geller, S.E.; Studee, L. Soy and red clover for mid-life and aging. Climacteric 2006, 9, 245-263. [CrossRef]

81. Booth, N.L.; Piersen, C.E.; Banuvar, S.; Geller, S.E.; Shulman, L.P.; Farnsworth, N.R. Clinical studies of red clover (Trifolium pratense) dietary supplements in menopause: A literature review. Menopause 2006, 13, 251-264. [CrossRef] [PubMed]

82. Park, Y.; Moon, H.-J.; Paik, D.-J.; Kim, D.-Y. Effect of dietary legumes on bone-specific gene expression in ovariectomized rats. Nutr. Res. Pract. 2013, 7, 185-191. [CrossRef] [PubMed] 
83. Byun, J.S.; Han, Y.S.; Lee, S.S. The Effects of Yellow Soybean, Black Soybean, and Sword Bean on Lipid Levels and Oxidative Stress in Ovariectomized Rats. Int. J. Vitam. Nutr. Res. 2010, 80, 97-106. [CrossRef]

84. Hinton, P.S.; Ortinau, L.C.; Dirkes, R.K.; Shaw, E.L.; Richard, M.W.; Zidon, T.Z.; Britton, S.L.; Koch, L.G.; Vieira-Potter, V.J. Soy protein improves tibial whole-bone and tissue-level biomechanical properties in ovariectomized and ovary-intact, low-fit female rats. Bone Rep. 2018, 8, 244-254. [CrossRef]

85. Akao, M.; Abe, R.; Sato, N.; Hasegawa-Tanigome, A.; Kumagai, H.; Kumagai, H. Prevention of Osteoporosis by Oral Administration of Phytate-Removed and Deamidated Soybean $\beta$-Conglycinin. Int. J. Mol. Sci. 2015, 16, 2117-2129. [CrossRef]

86. Choi, C.-W.; Choi, S.-W.; Kim, H.-J.; Lee, K.-S.; Kim, S.-H.; Kim, S.-L.; Do, S.H.; Seo, W.-D. Germinated soy germ with increased soyasaponin Ab improves BMP-2-induced bone formation and protects against in vivo bone loss in osteoporosis. Sci. Rep. 2018, 8, 12970. [CrossRef]

87. Noh, D.; Lim, Y.; Lee, H.; Kim, H.; Kwon, O. Soybean-Hop Alleviates Estrogen Deficiency-Related Bone Loss and Metabolic Dysfunction in Ovariectomized Rats Fed a High-Fat Diet. Molecules 2018, 23, 1205. [CrossRef]

88. Kim, J.-S.; Lee, H.; Nirmala, F.S.; Jung, C.H.; Jang, Y.-J.; Ha, T.-Y.; Ahn, J. Dry-Fermented Soybean Food (Cheonggukjang) Ameliorates Senile Osteoporosis in the Senescence-Accelerated Mouse Prone 6 Model. J. Med. Food 2019, 22, 1047-1057. [CrossRef]

89. Zakłos-Szyda, M.; Budryn, G.; Grzelczyk, J.; Pérez-Sánchez, H.; Żyżelewicz, D. Evaluation of Isoflavones as Bone Resorption Inhibitors upon Interactions with Receptor Activator of Nuclear Factor-kB Ligand (RANKL). Molecules 2020, 25, 206. [CrossRef]

90. Chen, W.-F.; Wong, M.-S. Genistein modulates the effects of parathyroid hormone in human osteoblastic SaOS-2 cells. Br. J. Nutr. 2006, 95, 1039-1047. [CrossRef]

91. Jung, W.-K.; Choi, I.-W.; Hong, G.-E.; Pyun, C.-W.; Park, K.-K.; Seo, S.-K.; Lee, C.-H. Effects of Isoflavone Aglycone-rich Fermented Soybean Paste Extracts on Osteoblastic Differentiation of MG-63 Cells. J. Korean Soc. Appl. Biol. Chem. 2010, 53, 803-809. [CrossRef]

92. Ho, M.-X.; Poon, C.C.-W.; Wong, K.-C.; Qiu, Z.-C.; Wong, M.-S. Icariin, but Not Genistein, Exerts Osteogenic and Anti-apoptotic Effects in Osteoblastic Cells by Selective Activation of Non-genomic ER $\alpha$ Signaling. Front. Pharmacol. 2018, 9, 474. [CrossRef]

93. Thangavel, P.; Puga-Olguín, A.; Rodríguez-Landa, J.F.; Zepeda, R.C. Genistein as Potential Therapeutic Candidate for Menopausal Symptoms and Other Related Diseases. Molecules 2019, 24, 3892. [CrossRef]

94. Chen, C.; Zheng, H.; Qi, S. Genistein and Silicon Synergistically Protects Against Ovariectomy-Induced Bone Loss Through Upregulating OPG/RANKL Ratio. Biol. Trace Element Res. 2018, 188, 441-450. [CrossRef]

95. Qi, S. Synergistic Effects of Genistein and Zinc on Bone Metabolism and the Femoral Metaphyseal Histomorphology in the Ovariectomized Rats. Biol. Trace Elem. Res. 2017, 183, 288-295. [CrossRef]

96. Hu, B.; Yu, B.; Tang, D.; Li, S.; Wu, Y. Daidzein promotes osteoblast proliferation and differentiation in OCT1 cells through stimulating the activation of BMP-2/Smads pathway. Genet. Mol. Res. 2016, 15. [CrossRef]

97. Jin, X.; Sun, J.; Yu, B.; Wang, Y.; Sun, W.J.; Yang, J.; Huang, S.H.; Xie, W.L. Daidzein stimulates osteogenesis facilitating proliferation, differentiation, and antiapoptosis in human osteoblast-like MG-63 cells via estrogen receptor-dependent MEK/ERK and PI3K/Akt activation. Nutr. Res. 2017, 42, 20-30. [CrossRef] [PubMed]

98. Wang, S.; Zhang, S.; Wang, S.; Gao, P.; Dai, L. A comprehensive review on Pueraria: Insights on its chemistry and medicinal value. Biomed. Pharmacother. 2020, 131, 110734. [CrossRef]

99. Li, B.; Liu, M.; Wang, Y.; Gong, S.; Yao, W.; Li, W.; Gao, H.; Wei, M. Puerarin improves the bone micro-environment to inhibit OVX-induced osteoporosis via modulating SCFAs released by the gut microbiota and repairing intestinal mucosal integrity. Biomed. Pharmacother. 2020, 132, 110923. [CrossRef] [PubMed]

100. Zhang, G.; Wang, Y.; Tang, G.; Ma, Y. Puerarin inhibits the osteoclastogenesis by inhibiting RANKL-dependent and -independent autophagic responses. BMC Complement. Altern. Med. 2019, 19, 269. [CrossRef]

101. Zhang, Y.; Zeng, X.; Zhang, L.; Zheng, X. Stimulatory Effect of Puerarin on Bone Formation through Activation of PI3K/Akt Pathway in Rat Calvaria Osteoblasts. Planta Medica 2007, 73, 341-347. [CrossRef]

102. Shan, Z.; Cheng, N.; Huang, R.; Zhao, B.; Zhou, Y. Puerarin promotes the proliferation and differentiation of MC3T3-E1 cells via microRNA-106b by targeting receptor activator of nuclear factor- $\mathrm{kB}$ ligand. Exp. Ther. Med. 2017, 15, 55-60. [CrossRef]

103. Ma, H.; He, X.; Yang, Y.; Li, M.; Hao, D.; Jia, Z. The genus Epimedium: An ethnopharmacological and phytochemical review. J. Ethnopharmacol. 2011, 134, 519-541. [CrossRef]

104. Jia, M.; Nie, Y.; Cao, D.-P.; Xue, Y.-Y.; Wang, J.-S.; Zhao, L.; Rahman, K.; Zhang, Q.-Y.; Qin, L.-P. Potential Antiosteoporotic Agents from Plants: A Comprehensive Review. Evid.-Based Complement. Altern. Med. 2012, 2012, 364604. [CrossRef]

105. Zhao, B.-J.; Wang, J.; Song, J.; Gu, J.-F.; Yuan, J.-R.; Zhang, L.; Jiang, J.; Feng, L.; Jia, X.-B. Beneficial Effects of a Flavonoid Fraction of Herba Epimedii on Bone Metabolism in Ovariectomized Rats. Planta Med. 2016, 82, 322-329. [CrossRef]

106. Xu, H.; Zhou, S.; Qu, R.; Yang, Y.; Gong, X.; Hong, Y.; Jin, A.; Huang, X.; Dai, Q.; Jiang, L. Icariin prevents oestrogen deficiencyinduced alveolar bone loss through promoting osteogenesis via STAT3. Cell Prolif. 2020, 53, e12743. [CrossRef]

107. Keiler, A.; Zierau, O.; Kretzschmar, G. Hop Extracts and Hop Substances in Treatment of Menopausal Complaints. Planta Med. 2013, 79, 576-579. [CrossRef] [PubMed]

108. Milligan, S.R.; Kalita, J.C.; Pocock, V.; Van De Kauter, V.; Stevens, J.F.; Deinzer, M.L.; Rong, H.; De Keukeleire, D. The Endocrine Activities of 8-Prenylnaringenin and Related Hop (Humulus lupulus L.) Flavonoids. J. Clin. Endocrinol. Metab. 2000, 85, $4912-4915$. [CrossRef] 
109. Ban, Y.-H.; Yon, J.-M.; Cha, Y.; Choi, J.; An, E.S.; Guo, H.; Seo, D.W.; Kim, T.-S.; Lee, S.-P.; Kim, J.-C.; et al. A Hop Extract Lifenol ${ }^{\circledR}$ Improves Postmenopausal Overweight, Osteoporosis, and Hot Flash in Ovariectomized Rats. Evid.-Based Complement. Altern. Med. 2018, 2018, 2929107. [CrossRef]

110. Keiler, A.M.; Helle, J.; Bader, M.I.; Ehrhardt, T.; Nestler, K.; Kretzschmar, G.; Bernhardt, R.; Vollmer, G.; Nikolić, D.; Bolton, J.L.; et al. A standardized Humulus lupulus (L.) ethanol extract partially prevents ovariectomy-induced bone loss in the rat without induction of adverse effects in the uterus. Phytomedicine 2017, 34, 50-58. [CrossRef]

111. Li, J.; Zeng, L.; Xie, J.; Yue, Z.; Deng, H.; Ma, X.; Zheng, C.; Wu, X.; Luo, J.; Liu, M. Inhibition of Osteoclastogenesis and Bone Resorption in vitro and in vivo by a prenylflavonoid xanthohumol from hops. Sci. Rep. 2015, 5, 17605. [CrossRef] [PubMed]

112. Jeong, H.M.; Han, E.H.; Jin, Y.H.; Choi, Y.H.; Lee, K.Y.; Jeong, H.G. Xanthohumol from the hop plant stimulates osteoblast differentiation by RUNX2 activation. Biochem. Biophys. Res. Commun. 2011, 409, 82-89. [CrossRef]

113. Luo, D.; Kang, L.; Ma, Y.; Chen, H.; Kuang, H.; Huang, Q.; He, M.; Peng, W. Effects and mechanisms of 8-prenylnaringenin on osteoblast MC 3T3-E1 and osteoclast-like cells RAW 264.7. Food Sci. Nutr. 2014, 2, 341-350. [CrossRef]

114. Arjmandi, B.H.; Johnson, S.A.; Pourafshar, S.; Navaei, N.; George, K.S.; Hooshmand, S.; Chai, S.C.; Akhavan, N.S. Bone-Protective Effects of Dried Plum in Postmenopausal Women: Efficacy and Possible Mechanisms. Nutrients 2017, 9, 496. [CrossRef]

115. Hooshmand, S.; Chai, S.C.; Saadat, R.L.; Payton, M.E.; Brummel-Smith, K.; Arjmandi, B.H. Comparative effects of dried plum and dried apple on bone in postmenopausal women. Br. J. Nutr. 2011, 106, 923-930. [CrossRef]

116. Simonavice, E.; Liu, P.-Y.; Ilich, J.Z.; Kim, J.-S.; Arjmandi, B.; Panton, L.B. The effects of a 6-month resistance training and dried plum consumption intervention on strength, body composition, blood markers of bone turnover, and inflammation in breast cancer survivors. Appl. Physiol. Nutr. Metab. 2014, 39, 730-739. [CrossRef] [PubMed]

117. Rajput, R.; Wairkar, S.; Gaud, R. Nutraceuticals for better management of osteoporosis: An overview. J. Funct. Foods 2018, 47, 480-490. [CrossRef]

118. Arjmandi, B.H.; Johnson, C.D.; Campbell, S.C.; Hooshmand, S.; Chai, S.C.; Akhter, M.P. Combining Fructooligosaccharide and Dried Plum Has the Greatest Effect on Restoring Bone Mineral Density Among Select Functional Foods and Bioactive Compounds. J. Med. Food 2010, 13, 312-319. [CrossRef]

119. Bu, S.Y.; Lucas, E.A.; Franklin, M.; Marlow, D.; Brackett, D.J.; Boldrin, E.A.; Devareddy, L.; Arjmandi, B.H.; Smith, B.J. Comparison of dried plum supplementation and intermittent PTH in restoring bone in osteopenic orchidectomized rats. Osteoporos. Int. 2007, 18, 931-942. [CrossRef] [PubMed]

120. Deyhim, F.; Stoecker, B.J.; Brusewitz, G.H.; Devareddy, L.; Arjmandi, B.H. Dried plum reverses bone loss in an osteopenic rat model of osteoporosis. Menopause 2005, 12, 755-762. [CrossRef]

121. Rendina, E.; Hembree, K.D.; Davis, M.R.; Marlow, D.; Clarke, S.L.; Halloran, B.P.; Lucas, E.A.; Smith, B.J. Dried Plum's Unique Capacity to Reverse Bone Loss and Alter Bone Metabolism in Postmenopausal Osteoporosis Model. PLoS ONE 2013, 8, e60569. [CrossRef]

122. Graef, J.L.; Ouyang, P.; Wang, Y.; Rendina-Ruedy, E.; Lerner, M.R.; Marlow, D.; Lucas, E.A.; Smith, B.J. Dried plum polyphenolic extract combined with vitamin $\mathrm{K}$ and potassium restores trabecular and cortical bone in osteopenic model of postmenopausal bone loss. J. Funct. Foods 2018, 42, 262-270. [CrossRef] [PubMed]

123. Bu, S.Y.; Lerner, M.; Stoecker, B.J.; Boldrin, E.; Brackett, D.J.; Lucas, E.A.; Smith, B.J. Dried Plum Polyphenols Inhibit Osteoclastogenesis by Downregulating NFATc1 and Inflammatory Mediators. Calcif. Tissue Int. 2008, 82, 475-488. [CrossRef]

124. Bu, S.Y.; Hunt, T.S.; Smith, B.J. Dried plum polyphenols attenuate the detrimental effects of TNF- $\alpha$ on osteoblast function coincident with up-regulation of Runx2, Osterix and IGF-I. J. Nutr. Biochem. 2009, 20, 35-44. [CrossRef]

125. Pereira, C.B.; Gomes, P.S.; Costa-Rodrigues, J.; Palmas, R.A.; Vieira, L.; Ferraz, M.P.; Lopes, M.A.; Fernandes, M.H. Equisetum arvense hydromethanolic extracts in bone tissue regeneration: In vitro osteoblastic modulation and antibacterial activity. Cell Prolif. 2012, 45, 386-396. [CrossRef] [PubMed]

126. Costa-Rodrigues, J.; Carmo, S.C.; Silva, J.C.; Fernandes, M.H. Inhibition of human in vitro osteoclastogenesis by Equisetum arvense. Cell Prolif. 2012, 45, 566-576. [CrossRef]

127. Kotwal, S.D.; Badole, S.R. Anabolic therapy with Equisetum arvense along with bone mineralising nutrients in ovariectomized rat model of osteoporosis. Indian J. Pharmacol. 2016, 48, 312-315. [CrossRef] [PubMed]

128. Arbabzadegan, N.; Moghadamnia, A.A.; Kazemi, S.; Nozari, F.; Moudi, E.; Haghanifar, S. Effect of Equisetum arvense extract on bone mineral density in Wistar rats via digital radiography. Casp. J. Intern. Med 2019, 10, 176-182.

129. EFSA Panel on Dietetic Products, Nutrition and Allergies (NDA). Scientific opinion on the substantiation of health claims related to Equisetum arvense L. and invigoration of the body (ID 2437), maintenance of skin (ID 2438), maintenance of hair (ID 2438), maintenance of bone (ID 2439), and maintenance or achievement of a normal body weight (ID 2783) pursuant to Article 13 of Regulation (EC) No 1924/2006. EFSA J. 2009, 7, 1289.

130. Zepelin, H.-H.H.-V. 60 years of Cimicifuga racemosa medicinal products. Wien. Med. Wochenschr. 2017, 167, 147-159. [CrossRef]

131. Dragos, D.; Gilca, M.; Gaman, L.; Stoian, I.; Lupescu, O. Osteoprotective medicinal plants-part 1 (A human clinical evidence-based review). Afr. J. Tradit. Complement. Altern. Med. 2017, 14, 102-119. [CrossRef]

132. Carlisle, A.P.; Jessup, J.V.; Simpson, S.; Yoon, S. Effect of black cohosh on biochemical markers of bone remodeling in postmenopausal women. J. Midwifery Women's Health 2009, 54, 424. [CrossRef]

133. Ahn, B.-S.; Yang, M.; Jang, H.; Lee, H.J.; Moon, C.; Kim, J.-C.; Jung, U.; Jo, S.K.; Jang, J.-S.; Kim, S.-H. Evaluation of the Antiosteoporotic Potential of Cimicifuga heracleifolia in Female Mice. Phytother. Res. 2011, 26, 663-668. [CrossRef] 
134. Li, J.; Liu, J.; He, C.; Yu, Z.; Du, Y.; Kadota, S.; Seto, H. Triterpenoids from Cimicifugae rhizoma, a novel class of inhibitors on bone resorption and ovariectomy-induced bone loss. Maturitas 2007, 58, 59-69. [CrossRef]

135. Choi, E.M. Deoxyactein stimulates osteoblast function and inhibits bone-resorbing mediators in MC3T3-E1 cells. J. Appl. Toxicol. 2011, 33, 190-195. [CrossRef]

136. Lee, Y.S.; Choi, E.M. Actein Isolated from Black Cohosh Promotes the Function of Osteoblastic MC3T3-E1 Cells. J. Med. Food 2014 17, 414-423. [CrossRef]

137. Guo, Y.; Li, Y.; Xue, L.; Severino, R.P.; Gao, S.; Niu, J.; Qin, L.-P.; Zhang, D.; Brömme, D. Salvia miltiorrhiza: An ancient Chinese herbal medicine as a source for anti-osteoporotic drugs. J. Ethnopharmacol. 2014, 155, 1401-1416. [CrossRef]

138. Dragos, D.; Gilca, M.; Gaman, L.; Vlad, A.; Iosif, L.; Stoian, I.; Lupescu, O. Phytomedicine in Joint Disorders. Nutrients 2017, 9 , 70. [CrossRef]

139. Kim, M.-H.; Jung, K.; Nam, K.-H.; Jang, H.-J.; Lee, S.W.; Kim, Y.; Park, C.S.; Lee, T.-H.; Park, J.H.; Choi, J.H.; et al. Salvia plebeia R.Br. inhibits signal transduction of IL-6 and prevents ovariectomy-induced bone loss by suppressing osteoclastogenesis. Arch. Pharmacal Res. 2016, 39, 1671-1681. [CrossRef]

140. Liu, H.; Zhu, R.; Wang, L.; Liu, C.; Ma, R.; Qi, B.; Chen, B.; Li, L.; Guo, Y.; Shi, S.; et al. Radix Salviae miltiorrhizae improves bone microstructure and strength through Wnt/ $\beta$-catenin and osteoprotegerin/receptor activator for nuclear factor- $\mathrm{kB}$ ligand/cathepsin K signaling in ovariectomized rats. Phytother. Res. 2018, 32, 2487-2500. [CrossRef]

141. Gupta, T.; Das, N.; Imran, S. The Prevention and Therapy of Osteoporosis: A Review on Emerging Trends from Hormonal Therapy to Synthetic Drugs to Plant-Based Bioactives. J. Diet. Suppl. 2018, 16, 699-713. [CrossRef]

142. Gan, D.; Xu, X.; Chen, D.; Feng, P.; Xu, Z. Network Pharmacology-Based Pharmacological Mechanism of the Chinese Medicine Rhizoma drynariae Against Osteoporosis. Med. Sci. Monit. 2019, 25, 5700-5716. [CrossRef] [PubMed]

143. Jang, S.-A.; Hwang, Y.-H.; Kim, T.; Lee, A.; Ha, H. Anti-Osteoporotic and Anti-Adipogenic Effects of the Water Extract of Drynaria roosii Nakaike in Ovariectomized Mice Fed a High-Fat Diet. Molecules 2019, 24, 3051. [CrossRef]

144. Sun, X.; Wei, B.; Peng, Z.; Chen, X.; Fu, Q.; Wang, C.; Zhen, J.; Sun, J. A polysaccharide from the dried rhizome of Drynaria fortunei (Kunze) J. Sm. prevents ovariectomized (OVX)-induced osteoporosis in rats. J. Cell. Mol. Med. 2020, 24, 3692-3700. [CrossRef]

145. Liu, Y.; Wang, C.; Wang, G.; Sun, Y.; Deng, Z.; Chen, L.; Chen, K.; Tickner, J.; Kenny, J.; Song, D.; et al. Loureirin B suppresses RANKL-induced osteoclastogenesis and ovariectomized osteoporosis via attenuating NFATc1 and ROS activities. Theranostics 2019, 9, 4648-4662. [CrossRef]

146. Zou, B.; Zheng, J.; Deng, W.; Tan, Y.; Jie, L.; Qu, Y.; Yang, Q.; Ke, M.; Ding, Z.; Chen, Y.; et al. Kirenol inhibits RANKL-induced osteoclastogenesis and prevents ovariectomized-induced osteoporosis via suppressing the Ca2+-NFATc1 and Cav-1 signaling pathways. Phytomedicine 2021, 80, 153377. [CrossRef]

147. Nowak, B.; Matuszewska, A.; Nikodem, A.; Filipiak, J.; Landwójtowicz, M.; Sadanowicz, E.; Jędrzejuk, D.; Rzeszutko, M.; Zduniak, K.; Piasecki, T.; et al. Oral administration of kaempferol inhibits bone loss in rat model of ovariectomy-induced osteopenia. Pharmacol. Rep. 2017, 69, 1113-1119. [CrossRef]

148. Wong, S.K.; Chin, K.-Y.; Ima-Nirwana, S. The Osteoprotective Effects of Kaempferol: The Evidence From In Vivo And In Vitro Studies. Drug Des. Dev. Ther. 2019, 13, 3497-3514. [CrossRef]

149. Nowak, B.; Matuszewska, A.; Szandruk, M.; Matkowski, A.; Woźniak, D.; Zduniak, K.; Rzeszutko, M.; Landwójtowicz, M.; Jędrzejuk, D.; Piasecki, T.; et al. Effect of long-term administration of mangiferin from Belamcanda chinensis on bone metabolism in ovariectomized rats. J. Funct. Foods 2018, 46, 12-18. [CrossRef]

150. Ding, L.-Z.; Teng, X.; Zhang, Z.-B.; Zheng, C.-J.; Chen, S.-H. Mangiferin inhibits apoptosis and oxidative stress via BMP2/Smad-1 signaling in dexamethasone-induced MC3T3-E1 cells. Int. J. Mol. Med. 2018, 41, 2517-2526. [CrossRef]

151. Sekiguchi, Y.; Mano, H.; Nakatani, S.; Shimizu, J.; Kataoka, A.; Ogura, K.; Kimira, Y.; Ebata, M.; Wada, M. Mangiferin positively regulates osteoblast differentiation and suppresses osteoclast differentiation. Mol. Med. Rep. 2017, 16, 1328-1332. [CrossRef]

152. Wong, S.K.; Chin, K.-Y.; Ima-Nirwana, S. Quercetin as an Agent for Protecting the Bone: A Review of the Current Evidence. Int. J. Mol. Sci. 2020, 21, 6448. [CrossRef] 